\title{
El acceso de don Gutierre de Sotomayor al Maestrazgo de la Orden de Alcántara: orígenes y consecuencias*
}

\section{Gutierre de Sotomayor's Access to the Mastership of the Order of Alcantara: Origins and Consequences}

\begin{abstract}
RESUMEN
El objetivo de este artículo es profundizar en el estudio de la historia política de la

Orden de Alcántara en el período de tiempo que abarca el maestrazgo de don Gutierre de Sotomayor (1432-1453). Para tal fin, nos hemos servido del estudio de su ascensión al maestrazgo y de su posterior actuación en la política de la convulsa Castilla del segundo cuarto del siglo XV. Para ello, se han utilizado tanto fuentes cronísticas y literarias, como documentación de archivo. En este sentido, sigue siendo crucial la aportación que ha supuesto para el desarrollo de las investigaciones la Colección Diplomática Medieval de la Orden de Alcántara, instrumento indispensable para todo aquél que quiera adentrarse en su estudio.
\end{abstract}

Javier Ortega Álvarez**

\section{PALABRAS CLAVE}

Castilla; Edad Media; Órdenes Militares Hispánicas; Orden Militar de Alcántara; Historia política.

\section{ABSTRACT}

The aim of this article is to delve further into the political history of the Order of Alcantara during the period of the Mastership of Gutierre de Sotomayor (1432-1453). We have focused on the study of his ascent to the Mastership and his subsequent participation in the turbulent politics of Castile during the second quarter of the fifteenth century. Our research has made use of chronicle and literary sources, as well as archival records. The contribution of the Colección diplomática medieval de la Orden de Alcántara is invaluable and has become an essential tool for the study of this Order.

\section{KEY WORDS}

Castile, Middle Ages, Spanish military orders, Military Order of Alcantara, political history.

\section{INTRODUCCIÓN ${ }^{* * *}$}

Como ya indicamos en un trabajo anterior, la figura de don Gutierre de Sotomayor, Maestre de la Orden de Alcántara durante los años 1432-1453 (y por ex-

* Fecha de recepción del artículo: 2011-3-4. Fecha de aceptación del artículo: 2011-3-23

** Diplomado de Estudios Avanzados. Cuerpo Facultativo de Archivos. C.e.: javier.ortega@mcu.es

*** Los distintos documentos consultados para la elaboración de este artículo se citan remitiendo al lector a la obra donde se encuentran publicados. 
tensión, la de la propia Orden), no ha merecido el mismo trato por parte de los distintos autores e investigadores que otros grandes personajes de la época1.

Si en dicho trabajo centramos nuestros esfuerzos en los aspectos relativos a la prosopografía de la orden, en el presente trataremos de poner algo de luz en el proceso que llevó a don Gutierre a ocupar la más alta magistratura de la misma. Asimismo, nos adentraremos en las consecuencias tanto personales como generales -en cuanto a su participación en la política general del Reino- que dicho acontecimiento generó. Con todo ello pretendemos contribuir al conocimiento de la historia política de la Orden de Alcántara, sirviéndonos del estudio del que fue uno de sus más importantes maestres.

Para ello abordaremos, en primer lugar, los orígenes del mismo don Gutierre, cuestión esta siempre sometida a conjeturas y controversias. A partir de este punto de partida pasaremos a diseccionar y examinar, por una parte, el proceso de ascenso al maestrazgo de la Orden para, por otra, estudiar el papel que desempeñó en las difíciles circunstancias vividas por la monarquía de Juan II en la primera mitad del siglo XV. Por último, pasaremos a analizar las consecuencias que en el orden personal - de consolidación de su status y proyección del linaje por él creado- le reportó el ostentar dicho cargo y posicionarse desde el primer momento del lado de don Álvaro de Luna.

\section{LOS ORÍGENES. PLANTEAMIENTO DE LA CUESTIÓN}

Muchas son las dudas que se nos presentan a la hora de abordar el siempre delicado tema de los orígenes. A menudo, las certezas de que disponemos sobre tal o cual personaje no pasan de ser meras conjeturas, falseadas noticias o medias verdades flotando en un mar de confusiones.

Para el caso que nos ocupa, las muchas preguntas que nos asaltan y surgen en torno a don Gutierre de Sotomayor podrían resumirse o englobarse en una: ¿cómo este personaje, llegó a manejar los hilos de la orden de Alcántara y, en función de lo anterior, se convirtió en una pieza clave del «juego político» del momento?

La vida de nuestro personaje se halla salpicada por una serie de hitos cronológicos; hitos cronológicos que configuran, en atención a su grado de importancia, la trayectoria de don Gutierre. Quizás sea conveniente establecer — dentro de esta cronología - un punto, un eje de bisagra a partir del cual estudiar su figura. Dicho eje vendría representado por una fecha que marcará un antes y un después en

\footnotetext{
1 JAVIER ORTEGA ÁLVAREZ, «La "Casa” de Don Gutierre de Sotomayor, Maestre de Alcántara: una aproximación a la prosopografía de la Orden de Alcántara», en Revista de Estudios Extremeños, Año 2010, Tomo LXVI, Número I, pp. 239-286. Nos remitimos a lo dicho en la Introducción de este trabajo, ya que es perfectamente atribuible y válido para el que ahora estamos presentando.
} 
la vida de don Gutierre de Sotomayor: la prisión del infante don Pedro llevada a cabo el 1 de julio de $1432^{2}$ y su posterior elevación al maestrazgo de Alcántara a lo largo de dicho mes. A pesar de la arbitrariedad de la elección, tenemos sobradas razones para obrar así. Entre otras, la de ser capaces de formular y establecer una serie de preguntas e hipótesis cuyas respuestas nos irán poniendo en condiciones de ir avanzando en nuestro propósito.

La primera cuestión a la que tenemos que hacer frente, por tanto, es saber quién es Gutierre de Sotomayor. ¿Quién es la persona que ha sido capaz de apresar al hermano del rey Alfonso V de Aragón, del rey Juan II de Navarra, del poderoso infante Enrique? ${ }^{3}$

\subsection{La sombra de Juan de Sotomayor}

Al hablar de los orígenes de don Gutierre de Sotomayor, más que remitirnos directamente al apellido Sotomayor, rama familiar ésta, «....al parecer, vinculada a la Orden de Alcántara desde el último tercio del siglo XIV ${ }^{4}$, debemos hacerlo a la figura de su tío, don Juan de Sotomayor, maestre de la orden de Alcántara, personaje al que, de una forma u otra, debe don Gutierre su posición alcanzada. Hermano de su madre Catalina de Sotomayor ${ }^{5}$, Juan de Sotomayor ingresará en la orden de Alcántara de la mano del infante Fernando de Antequera, del que era su maestresala, en el año 1408, tras la elección del infante don Sancho, hijo de Fernando, como maestre de la orden. Y lo hará nada menos que como Gobernador de la misma y comendador de Valencia de Alcántara 6 . Quizás sea este un hecho, el de su designación para dichos cargos, al que no se le haya prestado la debida atención. Si, por un parte, la vinculación de Juan de Sotomayor a la familia del regente es un hecho del mayor interés, puesto que explica perfectamente su futura actuación política favorable a los infantes de Aragón, también puede arrojarnos mucha luz a la hora de valorar en su justa medida la dimensión de los Sotomayor.

En principio, esa vinculación de la familia a la orden vendría acreditada por la presencia en la misma de Frey Pedro Alfonso de Sotomayor, «primer miembro de esa familia, de nombre conocido, que perteneció a la Orden Militar» ${ }^{7}$, quien, al pa-

2 Recogido en P. CARRILLO DE HUETE, Crónica del Halconero de Juan II, ed. Mata Carriazo, Madrid, 1946, pp. 131-132.

${ }^{3}$ Los estudios que con más atención se han centrado en su figura son el biográfico de M. MUÑOZ DE SAN PEDRO, Don Gutierre de Sotomayor, maestre de Alcántara (1400-1453), Diputación Provincial de Cáceres, Cáceres, 1949, y la excelente tesis de E. CABRERA MUÑOZ, El condado de Belalcázar (1444-1518), Córdoba, 1977. A ellos habrá que hacer continuas referencias durante el presente artículo.

4 CABRERA MUÑOZ, p. 84. Véase BONIFACIO PALACIOS MARTÍN, «La cuna y la sepultura. Algunos aspectos biográficos de Juan de Sotomayor, Maestre de la Orden de Alcántara», en Revista de las Órdenes Militares, Año 2003, núm. 2, pp. 127-159.

5 A. DE TORRES Y TAPIA, Crónica de la orden de Alcántara, 2 vols. Madrid, 1763, vol. II, p. 295.

6 ALVAR GARCÍA DE SANTA MARÍA, Crónica de Juan II de Castilla, ed. Carriazo, pp. 266-267.

7 Ibídem, p. 84. 
recer, ejerció como maestre durante el período comprendido entre los años 1367$1369^{8}$. Tras su renuncia voluntaria de la dignidad maestral como consecuencia de la ascensión a la misma de Frey Melen Suárez ${ }^{9}$, murió «...a las órdenes y en unión del Maestre Don Diego Gómez Barroso, en 1383, en lucha con el condestable de Portugal, Álvarez Pereira ${ }^{10}$.

Pero, como dijimos más arriba, fue con don Juan de Sotomayor con quien la familia logró ocupar un lugar de preeminencia en la orden, y con quien comenzó la verdadera biografía de su sobrino Gutierre. ¿Qué motivos se esconden tras la elección de Juan de Sotomayor, por parte de Fernando de Antequera, para ocupar un cargo de tal relevancia? Crónicas, genealogías y memoriales nos muestran a Juan de Sotomayor manteniendo una especial relación con Fernando; así, lo vemos como un "criado suyo ${ }^{11}$, «hechura del rey»"12, y ejerciendo el oficio de «maestresala» ${ }^{13}$ del infante. Una relación especial cuyo origen debemos buscarlo en la propia ascendencia de Juan. El 27 de octubre de 1409, en Barcelona, el papa Benedicto XIII expidió una bula absolviéndolo «...de la mácula contraída al profesar en la orden de Alcántara y obtener la encomienda de Valencia de Alcántara sin haber obtenido dispensa canónica de su defecto de natalidad» ${ }^{14}$. Las lecturas que podemos obtener del documento son varias. Por una parte, viene a corroborar la entrada de Juan de Sotomayor en la orden como consecuencia de su designación por Fernando de Antequera como gobernador de la misma, al ser elegido maestre el infante don Sancho, y no antes como pensaba Rades ${ }^{15}$. En segundo lugar, desmonta la supuesta filiación de Juan recogida en las diferentes fuentes de que disponemos ${ }^{16}$, al solicitarse dicha bula por «...defectum pateris de soluto genitus et soluta» ${ }^{17}$. En tercero, y quizás el más importante, nos pone en condiciones de profundizar en un estado de opinión defendido por Torres y Tapia: para el desempeño

${ }^{8}$ A. DE TORRES Y TAPIA, pp. 123-124.

9 Ibídem, pp. 124-125. En relación con Melen Suárez, Torres lo incluye en el linaje de los Sotomayor. La noticia de la renuncia, citando precisamente a Torres, es recogida como hecho excepcional por LUIS CORRAL VAL, Los monjes soldados de la orden de Alcántara en la Edad Media, Castellum, Madrid, 1999, p. 193.

${ }_{10}$ MUÑOZ DE SAN PEDRO, p. 14. El autor supone que pudiera ser abuelo de don Juan de Sotomayor, y bisabuelo de don Gutierre.

11 GARCÍA DE SANTA MARÍA, p. 266; TORRES Y TAPIA, p. 208; PÉREZ DE GUZMÁN, «Crónica del Príncipe don Juan II», en Crónica de los Reyes de Castilla (B.A.E. Vol. LXVIII), Madrid, 1953, p. 316.

12 JERÓNIMO DE APONTE, Lucero de la nobleza, Bibl. Nac., Madrid, MSS/11424, MSS/11225, p. 451; MENDOZA Y APONTE, Genealogías, Bibl. Nac., Madrid, MSS/11465, p. 397.

13 TORRES Y TAPIA, p. 208; GARCÍA DE SANTA MARÍA, p. 266.

14 BONIFACIO PALACIOS MARTÍN (dir.), Colección Diplomática Medieval de la Orden de Alcántara (1157?-1494), editorial Complutense, Madrid, 2000, t. I, doc. 769. (En adelante, Colección).

${ }_{15}$ MUÑOZ DE SAN PEDRO, p. 14. con ref. a DE RADES Y ANDRADA, Crónica de Alcántara, en Crónica de las tres Órdenes y Cavallerías de Sanctiago, Calatrava y Alcántara, Toledo, 1572, fol. 34 vto.

${ }_{16}$ El mismo Francisco de Rades [citando la Crónica de Juan II de Pérez de Guzmán] y el Sacristán Mayor dicen fue el Maestre hijo de Alonso de Sotomayor, caballero natural del Reino de Galicia, o según otros Hernando de Sotomayor, en TORRES Y TAPIA, p. 239; PEDRO DE ULLOA GOLFín, Memorial de la calidad y servicios de la Casa don Álvaro Francisco de Ulloa Golfín y Chaves, Madrid, 1675, nos dice que su padre fue Fernando de Sotomayor, Caballero de Galicia, p. 132; JERÓNIMO DE APONTE, p. 451, habla de su padre Hernando de Sotomayor, fue caballero muy noble.

17 Colección, doc. 769. 
de tal oficio, don Fernando «...no se había de servir en oficio tan lustroso de hombre hijodalgo como quiera, sino noble y de gran porte»18. Es decir, Juan de Sotomayor, a tenor de lo visto, parece no ser un cualquiera, sino, posiblemente, el hijo de algún alto personaje de la corte $y$, por lo que podemos deducir, muy allegado al infante ${ }^{19}$. Las consecuencias de todo ello no solamente se van a ver reflejadas en la posición alcanzada por el ahora Gobernador de la orden. Dicha posición de preeminencia alcanzará al resto de la familia, datándose a partir de «...entonces la iniciación del verdadero arraigo y preponderancia de la familia en Extremadura ${ }^{20}$. Resultado o producto del nepotismo que practicó, nepotismo con el que algún autor ha llegado incluso a caracterizar a la nueva etapa que se iniciaría ahora en la orden $^{21}$, fue don Gutierre de Sotomayor.

Nacido en el lugar de Raudona alrededor de $1400^{22}$, don Gutierre pasó su infancia en Valencia de Alcántara ${ }^{23}$, al abrigo de su tío el comendador de la misma, como consecuencia de la política de nepotismo ya apuntada. El encumbramiento de Juan de Sotomayor en el seno de la Orden de Alcántara atrajo hacia él a diversos miembros de su familia, entre ellos a su cuñado Gil García de Raudona, casado con su hermana Catalina, matrimonio del cual nació el futuro maestre don Gutierre $^{24}$. La muerte de ésta llevó aparejado el traslado de la familia a Extremadura, buscando la protección del cuñado y la ayuda de su cuñada, Doña Juana González de Sotomayor, que había casado en estas tierras, para la crianza de sus hijos. Pronto ingresó Gil como Caballero en la Orden de Alcántara, ya que su viudez le permitía hacer el voto de castidad ${ }^{25}$.

Con la muerte del infante don Sancho en 1416, Juan de Sotomayor obtuvo la dignidad de maestre, siendo elegido canónicamente tras resistir la orden todas las presiones ${ }^{26}$. Pronto hubo Sotomayores y Raudonas —que también vinieron al amparo del parentesco los familiares de Don Gil- en los múltiples cargos y encomiendas que fueron vacando en años sucesivos. (...) Don Gutierre, Clavero

18 TORRES Y TAPIA, p. 241. Las opiniones recogidas de Torres y Tapia en este trabajo las consideramos con el máximo de las cautelas, ya que en muchas ocasiones no son sino opiniones nacidas de su deseo por engrandecer a la orden de Alcántara.

19 ¿Sería arriesgado por nuestra parte plantear el que también su hermana Catalina de Sotomayor, madre de don Gutierre, estuviese sujeta al mismo defecto de natalidad?

20 Según la opinión de MUÑOZ DE SAN PEDRO, p. 14.

21 LUIS CORRAL VAL, Los monjes soldados de la orden de Alcántara en la Edad Media (su organización institucional y vida religiosa), Madrid, 1999, p. 173.

22 MUÑOZ DE SAN PEDRO, p. 15 con las cautelas recogidas en la nota 8 de la misma.

23 Así lo afirma él mismo en una carta concedida a la villa de Valencia de Alcántara, fechada en Zalamea el 6 de febrero de 1434, a la cual eximía del pago del pedido, entre otras razones, por haberse criado allí el maestre. Recogido en Colección, doc. 889.

24 CABRERA MUÑOZ, p. 85.

25 MUÑOZ DE SAN PEDRO, p. 16.

26 Recordemos que Catalina [madre de Juan II] hubiera querido introducir un patrocinado, Gómez Carrillo de Cuenca, ayo del rey, pero los comendadores procedieron a una elección regular y designaron a Juan de Sotomayor. A ello contribuyó, sin duda, el control que el hasta entonces Gobernador mantenía sobre la orden. Benedicto XIII ordenó respetar la decisión del capítulo. L. SUÁREZ FERNÁNDEZ, Los Trastámaras de Castilla en el siglo XV, en Historia de España de Menéndez Pidal, vol. XV, p. 47. 
desde poco después de la elección de su tío y luego Comendador mayor. Su hermano don Juan, fue a la encomienda de Lares; el padre de ambos, Don Gil, a la de Piedrabuena; un hermano de éste, Don Gutierre de Raudona, a la de Valencia; su primo Gonzalo de Raudona, a la de Herrera; su otro primo, Alfonso Topete, hijo de su tía Doña Juana González, a la de Belvís; el pariente Sancho de Sotomayor, a la de Magacela ${ }^{27}$.

Fue a partir de estos años, con su inclusión en la orden de Alcántara de manos de su tío, cuando comenzó el cursus honorum de don Gutierre. En 1426 dejó la Clavería para regir la Encomienda Mayor, vacante por muerte de Rodrigo Rodríguez de Godoy. Antes de 1431 le fueron acumulados los cargos de Comendador de Portezuelo, a la muerte de Don Juan de Soto, y de Guarda Mayor del Príncipe de Asturias (nacido en 1425) por fallecimiento de su padre, Gil García de Raudona ${ }^{28}$.

Asentado sólidamente en la orden, los acontecimientos que se van a vivir en Castilla por estos años y su particular actuación dentro de ese contexto, catapultarán a don Gutierre de Sotomayor al primer plano del juego político del momento.

\subsection{Circunstancias políticas}

Dicha actuación debemos circunscribirla al cambio de panorama que experimentó Castilla, en general, y Extremadura, en particular, durante los últimos años de la década de los 20 y los primeros de la de los 30 del siglo XV, en un nuevo episodio del enfrentamiento entre los Infantes de Aragón y don Álvaro de Luna.

De los cuatro frentes que llegaron a constituirse a lo largo de la contienda ${ }^{29}$, el de la guerra en Extremadura es, por lo que atañe a la naturaleza de nuestro trabajo, el que más nos interesa. Ámbito de actuación de los infantes don Enrique y don Pedro durante gran parte de la campaña ${ }^{30}$, lo fue, asimismo, de la orden de Alcántara, y, sobre todo, de su maestre.

\subsection{La guerra en Extremadura y la ascensión de don Gutierre}

Las operaciones militares en Extremadura comenzaron cuando, a primeros de agosto de 1429, el conde de Benavente, Rodrigo Alonso Pimentel, se apoderó de

27 MUÑOZ DE SAN PEDRO, pp. 16-17.

${ }_{28}$ MUÑOZ DE SAN PEDRO, p. 18. La noticia del cargo de Guarda Mayor del príncipe, ostentado por Gil García de Raudona, viene recogida en PEDRO DE ULLOA GOLFÍN, Memorial, p. 132.

${ }_{29}$ Las fronteras valencianas, aragonesas y navarras y la guerra en Extremadura... son los cuatro frentes en que divide las operaciones MIGUEL GUAL CAMARENA, «Las treguas de Majano entre Aragón, Navarra y Castilla (1430), en Cuadernos de Historia de España, XVI, 1951, pp. 79-109, p. 86.

30 Un estudio, cuya base lo constituye el relato de las crónicas de esta actuación, en LINO DUARTE INSÚA, Los infantes de Aragón en Extremadura, en Revista del Centro de Estudios Extremeños, XI, 1937, pp. 49-74, 145-166, 273-314; XII, 1938, pp. 91-104, 163-186, 325-343 y XIII, 1939, pp. 271-285. 
la ciudad de Ocaña y expulsó del maestrazgo de Santiago al infante don Enrique, instalado allí. Ante lo comprometido de su situación, el infante optó por refugiarse en Extremadura, donde contaba con sus mejores tropas y sus más sólidos castillos y fortalezas: Alburquerque, Trujillo, y Segura de la Sierra. Aquí se le unió pronto su hermano Pedro, que había podido reunir dinero fingiendo sumisión al rey ${ }^{31}$. A partir de entonces, la unión de fuerzas de ambos hermanos y el inicio de sus correrías llevaron a la intervención directa en la zona del propio don Álvaro de Luna. Éste ocupó Trujillo cercando, a continuación, Montánchez y Piedrabuena.

Todos los autores coinciden a la hora de señalar la difícil situación que se le presentaba al entonces maestre don Juan de Sotomayor con la presencia en la zona de don Enrique y don Pedro, ya que estaba, por una parte, muy ligado a la Casa de los infantes y obligado, al mismo tiempo, a mantenerse en la obediencia del rey ${ }^{32}$. Presente en Palencia en el juramento de fidelidad exigido por el monarca ante la proximidad de la guerra contra los reyes de Aragón y Navarra ${ }^{33}$, la posición del maestre osciló sin atreverse a tomar abiertamente partido. Por el momento, en la campaña que llevó a cabo el condestable sobre los bastiones extremeños de los infantes, el maestre, como anota Muñoz de San Pedro, cooperó con las fuerzas reales, haciéndolo junto a su predilecto Don Gutierre ${ }^{34}$. Como apuntamos anteriormente, es este período el que marca el inicio de su «actuación política», una actuación ligada inexorablemente a la de su tío. Pensamos que esta toma de contacto se habría producido antes, durante la entrada del rey Juan II en territorio de la Corona de Aragón. Resulta plausible, en consonancia con lo apuntado, que junto al maestre, que acompañó al rey en la campaña ${ }^{35}$, fuese el predilecto sobrino, así como a la vuelta del monarca a Peñafiel, una vez expropiadas las tierras de los infantes ${ }^{36}$.

Estos primeros contactos se acentuaron con la intervención directa del maestre de Alcántara en el conflicto. La tenaz resistencia que opusieron al cerco Montánchez y Piedrabuena, hizo que don Álvaro reclamase la presencia de Juan II. Acompañando al rey a su llegada a Cáceres el 20 de diciembre, se encontraba el

31 CRÓNICA DE JUAN II, p. 466. Es obligatorio recordar que esa sumisión se produjo tras los pactos firmados para la entrega de la ciudad de Peñafiel, en cuyas negociaciones tuvo una actuación singular don Juan de Sotomayor, como se recoge en CARRILLO DE HUETE, p. 36, «E luego el infante don Pedro e el conde de Castro enviaron por el ovispo de Palencia, don Gutierre de Toledo, e por el maestre de Alcántara, don Juan de Sotomayor, e movieron tratos tales que se entregó la villa e el castillo de Peñafiel». Quizás no sea descabellado añadir que además de tropas y fortalezas, los infantes también contaban - ¿o así lo creían ellos? - con su mejor aliado en la zona, el maestre de Alcántara.

32 CABRERA MUÑOZ, p. 86.

33 TORRES Y TAPIA, p. 264.

34 MUÑOZ DE SAN PEDRO, op. cit., p. 20 Por estos buenos y señalados servicios, se le concede la jurisdicción criminal del lugar de Rollán, cit. en TORRES Y TAPIA, p. 267.

35 GONZALO CHACÓN, Crónica de don Álvaro de Luna,, ed. y est. Mata Carriazo, Madrid, 1940, p. 92.

${ }^{36}$ El maestre de Alcántara es, entre otros, uno de los que acompañan al rey, en CARRILLO DE HUETE, p. 42. Así lo encontramos en Valladolid, el 30 de agosto, donde se le hace confirmación de la Cédula Real por la que se le concedía la jurisdicción criminal del lugar de Rollán, cit. en TORRES Y TAPIA, pp. 268-269. 
maestre de Alcántara, quien también lo acompañó al castillo de Montánchez $z^{37}$, que se entregó a las fuerzas reales el día 24 de dicho mes. Tras un ataque sin mucho éxito al castillo de Alburquerque en los primeros días de enero de 1430, el rey emprendió el regreso a Medina del Campo, dejando al maestre de Alcántara por frontero contra los infantes en calidad de capitán general de un ejército repartido entre Valencia, Piedrabuena, Mayorga, Mérida y Badajoz ${ }^{38}$.

El 17 de febrero de 1430 fue aprobada por el Consejo Real, reunido en Medina del Campo, la confiscación de las posesiones de los infantes. En el reparto, Don Juan de Sotomayor recibió Alconchel ${ }^{39}$. Torres y Tapia achacó esta donación quizás intentando justificar de alguna forma la posterior actuación del maestre en beneficio de los infantes - a la queja presentada por el maestre, ya que «...cuando el Rey repartió las Villas, Castillos y demás haciendas de los infantes, no le hizo a él merced de dar alguna. Estaba persuadido lo tenía merecido tanto como el que más, y juzgaba por gran mengua de reputación este desvío, habiéndole hecho casi singular entre todos los demás del Reyno de su porte» ${ }^{40}$. Fuere por una u otra razón, lo cierto es que a partir de este momento la situación dio un vuelco provocado por el giro en la política del maestre. Al rey comenzaron a llegarle nuevas de la ayuda que el maestre prestaba a los infantes ${ }^{41}$. No obstante, el rey siguió confiando en don Juan, como lo demuestra el que ordenase a Lorenzo Suárez de Figueroa que acudiese a Badajoz, a ponerse bajo las órdenes del maestre de Alcántara, para defender la ciudad de los infantes don Enrique y don Pedro ${ }^{42}$. Con la repulsa de éstos a las condiciones impuestas en las Treguas de Majano (firmadas el 16 de julio entre Castilla y Aragón), la difícil situación del maestre se agudizó. Juan de Sotomayor optó por aliarse con aquellos que, en aquel momento, consideró más cercanos e ingresó en el partido de los infantes, aunque conservando siempre cierta vacilación que causaba en la corte la natural suspicacia ${ }^{43}$. Ante esto, Juan II ensayó una política de acercamiento al maestre. Diferentes emisarios fueron enviados para tal propósito, como su secretario, Sancho Romero, o su halconero mayor, Pedro Carrillo de Huete. Una nueva embajada se produjo en 1431; en esta ocasión los emisarios - hombres de confianza de don Álvaro como en ante-

37 CARRILLO DE HUETE, p. 46.

38 Ibídem, p. 50.

39 CARRILLO DE HUETE, p. 52.

40 TORRES Y TAPIA, p. 274. De la misma opinión es Muñoz de San Pedro, para quien esta merced se le habría concedido una vez que el rey Juan II hubiese pospuesto la entrada en el reino de Granada ante lo avanzado de la estación, poniendo de nuevo la vista en los asuntos de Extremadura alarmado ya por la dudosa conducta del maestre.

41 La versatilidad política del Maestre de Alcántara habría comenzado a preocupar a Juan II en los meses estivales de 1430 ya que le mandó entregar el castillo de Barcarrota al señor de Feria Lorenzo Suárez de Figueroa y también porque consiguió una autorización del papa para proceder contra los miembros de las órdenes militares que respaldaban al infante Enrique, en JOSÉ LUIS DEL PINO GARCÍA, Extremadura en las luchas políticas del siglo XV, Badajoz, 1992, pp. 180-181. La cédula en la que se le ordena la entrega de Barcarrota está fechada en Amusco, el 13 de abril de 1430, en Colección, doc. 858.

42 1430, abril, 28, Colección, doc. 859.

${ }^{43}$ CABRERA MUÑNOZ, p. 86. 
riores ocasiones - fueron el doctor Diego González Franco y el obispo de Palencia don Gutierre Gómez de Toledo (amigo del maestre) ${ }^{44}$. En Ceclavín se firmaron las oportunas capitulaciones, mediante las cuales el maestre hizo pleito homenaje de servir fielmente al rey no dando favor a los infantes. Asimismo y, nota importante para nuestro trabajo, como garantía de su cumplimiento, dio al Rey en rehenes tres sobrinos suyos: Frey Gutierre de Sotomayor, Comendador Mayor de Alcántara; Frey Juan de Sotomayor, Comendador de Lares; y Fernando de Sotomayor, hermano de los dos $^{45}$.

No sabemos si el comendador mayor pasó algún tiempo o no en la Corte. Si fue así, su permanencia en la misma pudo ser, tal vez, de mucha utilidad a don Gutierre para poner en claro sus ideas. La actitud ambigua de su tío, y el peligro que ello representaba, le ponían en evidencia la necesidad de alinearse claramente en uno de los bandos. Si decidió o no don Gutierre el partido que a partir de entonces seguiría de manera inquebrantable durante el resto de su vida, es algo difícil de dilucidar. M. Muñoz de San Pedro se preguntaba si en la actitud de don Gutierre cabía ver indicios del ancestral caciquismo extremeño que alistaba miembros de una familia en distintos bandos o partidos: el sobrino con el condestable; el tío, con los infantes de Aragón ${ }^{46}$. Sea como fuere, y a juzgar por las noticias que de esta situación nos han quedado, lo cierto es que la estrella del comendador mayor comenzó a brillar con más fuerza. Lo que no implica que su tío, el maestre, sufriese un imparable declive. Muy al contrario, tanto el rey como los infantes intentaron en aquel momento atraerlo a toda costa a sus respectivos bandos, ofreciéndole, en el caso de los infantes, recompensa mayor de la que podían permitirse ${ }^{47}$.

\subsubsection{La apuesta política de don Gutierre}

Durante el otoño de 1431 los infantes don Enrique y don Pedro se prepararon nuevamente para la guerra, esperando contar para ello con el apoyo de Portugal48, y, sobre todo, con el del maestre de Alcántara. Así pudo constatarlo en Lisboa el doctor Franco, enviado allí para la confirmación de los tratados de paz con el país vecino ${ }^{49}$. La respuesta de Juan II no se hizo esperar. En octubre de 1431 envió a Lorenzo Suárez de Figueroa a defender la tierra de Badajoz y, al año siguiente, comisionó a Extremadura al abad mayor de Toledo, Juan Carrillo, para incautar las rentas del maestrazgo, ordenando a las ciudades, villas y alcaides no acogiesen a Juan de Sotomayor en sus castillos y fortalezas ${ }^{50}$. Junto a esta políti-

44 PEDRO A. PORRAS ARBOLEDA, Juan II, 1406-1454, Palencia, 1995.

45 TORRES Y TAPIA, p. 276.

46 CABRERA MUÑOZ, pp. 86-87.

47 Ibídem, p. 87.

48 Allí se encontraban el depuesto obispo de Coria, y sus hermanas las infantas Catalina y Leonor de Aragón casada, ésta última, con Duarte de Portugal.

49 SUÁREZ FERNÁNDEZ, Los Trastámaras en..., p. 133.

50 DEL PINO GARCÍA, Extremadura en las luchas..., p. 181, con ref. a RADES Y ANDRADA, fol. 39. 
ca de mano dura practicó también el diálogo; así, fueron enviados a Alcántara el obispo de Cuenca, don Álvaro de Osorna, y el licenciado Paz, con el intento de asegurar la fidelidad del maestre ${ }^{51}$. Nada pudo hacerse ante el rechazo de éste a cualquier trato, máxime cuando en el convento de Alcántara se hallaba ya el infante don Pedro. Pero, en una de las piruetas que caracterizaron su ambigua actitud, en cuanto se fueron los emisarios mandó tras ellos al clavero Martín de Manjarrés, haciéndoles saber que estaba dispuesto a acatar la autoridad del rey ${ }^{52}$. Señala Porras Arboledas cómo había en el entorno del maestre personas que eran partidarias de los infantes y otras que lo eran del rey, hallándose entre estos últimos el clavero Manjarrés y el secretario del maestre Andrés López del Castillo y cómo, con su influencia, le hacían cambiar continuamente de opinión. A ellos habría que añadir, como señala por su parte Muñoz de San Pedro, a Gonzalo Sánchez Topete y a su sobrino don Gutierre. En la carta de traspasamiento que don Gutierre hizo del cargo de Guarda del Príncipe a favor de su tío Gonzalo Sánchez Topete, queda expuesta claramente la línea de actuación de estos últimos en tan convulsos momentos ${ }^{53}$. Don Álvaro de Luna dio un paso más, haciendo pública, en marzo de 1432, la destitución del maestre de Alcántara ${ }^{54}$.

Por enésima vez y a pesar de la citada destitución, Juan II intentó la negociación. El 16 de mayo de 1432 partieron el adelantado Pedro Manrique y el almirante don Fadrique con 1200 hombres de armas con un doble propósito: estorbar a los infantes en Cáceres y su tierra y asegurar a Juan de Sotomayor en su cargo, anulando por tanto la destitución, si éste abandonaba el partido de los infantes y volvía consecuentemente a la obediencia real ${ }^{55}$. Inclinándose éste hacia la negociación, en un intento por mantenerse a la cabeza del maestrazgo, obtuvo de nuevo el perdón real. En ello tuvo mucho que ver la mediación del infante don Enrique de Portugal, ante el cual se firmaron los acuerdos concertados entre los emisarios del maestre, el clavero don Martín de Manjarrés y Gonzalo Sánchez Topete, y el doctor Franco ${ }^{56}$. Por estos acuerdos se le volvía a reconocer como maestre y se le daban seguridades en nombre del monarca, dispensándole de acudir a la

51 MUÑOZ DE SAN PEDRO, p. 26.

52 DEL PINO GARCÍA, p. 182.

53 «...y vos, el dicho Gonçalo Sánchez Topete siempre servistes derechamente a don Juan de Sotomayor, maestre de la dicha horden de Alcántara, mi tío, aconsejándole siempre que dexase la opinión de los infantes don Enrique e don Pedro, e feziese todas las cosas quel rey nuestro señor le enviaba a decir e mandar', en Colección, doc. 871. Esta actitud queda asimismo reivindicada y reflejada en JERÓNIMO DE APONTE, p. 451, y en MENDOZA Y APONTE, p. 397, los cuales, en similares términos, apuntan los innumerables ruegos que el comendador mayor hizo a su tío para que abandonase el partido de los infantes.

54 ALVAR GARCÍA DE SANTA MARÍA, pp. 338-339.

${ }^{55}$ CARRILLO DE HUETE, p. 129.

56 Los esfuerzos de los infantes por intentar abortar estos acuerdos, ya que los ponían entre las cuerdas, quedan patentes en la citada carta de traspasación de don Gutierre de Sotomayor a su tío: «...e otrosí por quanto en las envaxadas quel dicho maestre mi tío vos enbió a Portugal quando fuiste al infante don Enrique de Portugal sobre los tractos que él tenía con el dicho señor rey e el dicho maestre mi tío, por la dicha razón los dichos infantes don Enrique e don Pedro mandaron que ende doquier que vos fallasen que vos matasen e por mandado dellos vos aguardaron los caminos para vos matar...", en Colección, doc. 871. 
corte. El doctor Franco, invitado a la villa de Alcántara, acudió a la misma el 28 de junio de 1432: allí debía recoger del maestre la confirmación del acuerdo ${ }^{57}$. Una vez en la villa, el maestre volvió a pedir nuevas seguridades por parte del rey, a lo que el doctor Franco asintiós8. Sin embargo, de nada sirvieron tales tratos ya que el maestre, en ejecución de lo tratado con los infantes, apresó al doctor Franco —al que de nada valieron ni sus intentos de huida ni los de convencer al maestre de las desastrosas consecuencias de su acción-, e hizo llamar a éstos, que se encontraban en Alburquerque ${ }^{59}$. El encargado de la custodia del doctor fue don Gutierre de Sotomayor.

El encuentro entre ambos personajes es un elemento esencial a la hora de valorar la futura actuación del comendador mayor, ya que las conversaciones entabladas entre preso y guardián actuaron como catalizador de la situación, acelerando el desenlace de los acontecimientos ${ }^{60}$. Que la conversación caló hondo en el ánimo del comendador es algo fuera de toda duda, como muy pronto vino a demostrarse. ¿Conocía el doctor Franco al comendador mayor? Realizar una proposición de tal calibre en las extremas circunstancias en que se encontraba entrañaba un grave riesgo, a no ser que la persona a la que iba dirigida participase de idénticas inquietudes, máxime si tenemos en cuenta las relaciones tanto de parentesco como de gratitud que le unían con el maestre. Entramos aquí en un punto, el de la actuación de don Gutierre de Sotomayor, no exento de una cierta controversia. Cuestión que examinaremos más adelante.

\subsubsection{La prisión del infante don Pedro}

El domingo, 29 de junio, el maestre don Juan de Sotomayor entregó la villa de Alcántara, así como su fortaleza y convento, al infante don Pedro, a cuyas órdenes se puso don Gutierre hasta tanto ocupase las fortalezas de Magacela y Benquerencia, haciendo entrega a don Enrique del doctor Franco. De allí partieron ambos: don Enrique hacia Alburquerque, y el maestre hacia Valencia con la intención de refugiarse en su fortaleza y guardar los tesoros que llevaba consigo; una vez instalado, daría la orden para que los alcaides de las fortalezas del maestrazgo hiciesen pleito homenaje en las personas de los infantes, según se había acordado entre ellos ${ }^{61}$. Como tantas otras veces había ocurrido, el maestre cambió en última

57 SUÁREZ FERNÁNDEZ, Los Trastámaras..., p. 135. Al parecer, según MUÑOZ DE SAN PEDRO, op. cit., p. 29, nota n.ํ 36, con ref. al Centón Epistolario, epístola LIII, como ocurrió en Ceclavín, el maestre dejaba en manos del rey, como garantía de su cumplimiento, a sus tres sobrinos. Si ya hemos de ser cautos en ocasiones a la hora de citar las opiniones del conde de Canilleros, mucho más debemos serlo cuando aparece como una de sus fuentes, apoyando sus aseveraciones, el Centón Epistolario, como sabemos, obra apócrifa.

58 TORRES Y TAPIA, p. 281.

59 Ibídem, p. 281. Al parecer, el maestre había acordado con ellos la entrega de las fortalezas de su maestrazgo.

60 TORRES Y TAPIA, p. 282; Crónica de Juan II, p. 507.

61 TORRES Y TAPIA, p. 283. 
instancia de plan, dirigiéndose junto al infante a Alburquerque. Desconfiado y receloso de los infantes mantuvo, al parecer, una conversación con su sobrino antes de partir: en ella le persuadió de que, caso que el infante don Enrique apresase su persona y tesoros, hiciese él lo mismo con el infante don Pedro, asegurando con ello su vida y estado62. De esta forma, todo vino a aliarse para que la delicada y arriesgada acción que el comendador mayor pensaba llevar a cabo se realizase: lo que fue un simple cambio de planes se convirtió - así quiso creerlo- en la supuesta traición de don Enrique, quien habría apresado al maestre recluyéndolo en el castillo de Alburquerque ${ }^{63}$. De igual modo fue utilizado en su beneficio el descontento causado por las expediciones de castigo que el infante don Pedro llevó a cabo sobre Brozas, Belvís y Valencia de Alcántara, al instrumentalizar y contar con el apoyo del sector popular de Alcántara ${ }^{64}$. Por otra parte y mucho más importante, contaba con el apoyo real y la promesa del maestrazgo.

El día 1 de julio, a la hora de la siesta y acompañado por vecinos de la villa, se dirigió al convento de la orden y, penetrando en la cámara del infante, que se encontraba allí alojado, lo tomó preso $0^{65}$. Ante la previsión de un posible ataque y con el fin de asegurar el golpe, pidió ayuda al concejo de la villa de Alcántara que acudió a prestársela ${ }^{66}$. Cuatro días después, llegaban nuevas al rey de lo que había ocurrido ${ }^{67}$.

Llegados a este punto, se impone volver a la controversia arriba apuntada sobre la actuación de don Gutierre de Sotomayor. La Crónica de Juan II afirmaba su participación en los desmanes cometidos por los infantes, así como la prisión, a instancias suyas, del clavero Martín de Manjarrés y de Andrés López del Castillo68. Muñoz de San Pedro, sin embargo, desmintió en su momento lo relatado en dicha crónica, alegando incluso la enemistad profesada por Pérez de Guzmán contra tío y sobrino como una de las causas de dichas acusaciones ${ }^{69}$. Caracterizada por su fiabilidad, y «...obra cumbre de la historiografía de la Orden de Alcántara.»70, la crónica de Torres y Tapia atribuyó a don Juan de Sotomayor el prendimiento del doctor Franco, librando de toda culpa a su sobrino ${ }^{71}$. Por nuestra parte, nos inclinamos por esta segunda opción, no faltando razones para ello. Porque lo cierto es que la

62 Ibidem, p. 283, RADES Y ANDRADA, fol. 39 y 40, cit. por MUÑOZ DE SAN PEDRO, p. 30, nota n.․․ 41.

${ }^{63}$ Eso al menos fue lo que le comunicó su tío don Gutierre de Raudona, comendador de Valencia, en TORRES Y TAPIA, p. 283.

64 B. R. A. H., Col. Salazar, Mss. C-14, fol. 508 y ss, cit en CABRERA MUÑOZ, p. 88.

65 CARRILLO DE HUETE, pp. 131-132.

66 Crónica de Juan II, p. 508.

67 CARRILLO DE HUETE, p. 132.

68 Crónica de Juan II, p. 507. DEL PINO GARCÍA, p. 183 y PORRAS ARBOLEDA, p. 187 no dudan, siguiendo a este cronista, de tales afirmaciones.

69 MUÑOZ DE SAN PEDRO, nota n.․ 34, pp. 27-28, con ref. a RADES Y ANDRADA, fol. 42.

70 BONIFACIO PALACIOS MARTÍN, «Las primeras definiciones impresas de la Orden de Alcántara y los orígenes de su historiografía", en Estudios sobre las órdenes militares, Madrid, 2001, pp. 63-90, p. 90.

71 TORRES Y TAPIA, pp. 284-285. CABRERA MUÑOZ, p. 88, citando a Suárez Fernández, se muestra de la misma opinión que Torres. 
orden de Alcántara no era una balsa de aceite, reconociéndose problemas en su seno. El maestre no se hallaba respaldado del todo por sus caballeros: resulta cuanto menos sintomático que el infante don Pedro, una vez apoderado de la fortaleza y el convento de San Benito de Alcántara, realizase expediciones de castigo sobre Belvís, Brozas, o Valencia de Alcántara, acompañado incluso en esta última por Juan de Sotomayor. ¿Una situación de absoluta normalidad habría requerido semejante castigo ${ }^{72}$. Pero lo que resulta aún más llamativo es que dichas plazas se hallaban adscritas a la Encomienda Mayor ${ }^{73}$, cuyo titular era don Gutierre. Asimismo, al frente de la encomienda de Belvís se encontraba don Alonso Topete, hijo de Gonzalo Sánchez Topete y, por lo tanto, primo del comendador mayor y, de la de Valencia, don Gutierre de Raudona, su tío, ambos personajes muy allegados a él. Es decir, dichos ataques fueron dirigidos contra aquellos núcleos y personas que no acataban la autoridad establecida, encarnada ésta, no ya tanto en la figura del maestre como en la de los infantes. El doctor Franco sabía, en respuesta a la pregunta que formulamos en su momento, la tecla que debía tocar; no en vano, ya había conocido a don Gutierre tras la firma de los acuerdos de Ceclavín, en los que había quedado como su rehén, de la misma forma que a algunos de sus más allegados, como Gonzalo Sánchez Topete, con quien había negociado en Portugal. Es obvio, consecuentemente, que conocía la existencia de la disparidad de opiniones, como no lo es menos la jugada del comendador mayor: encargándose de la custodia del doctor supo acercarse a él en el momento oportuno, permaneciendo, posteriormente, al lado del infante don Pedro en Alcántara para lograr sus objetivos.

\subsection{Don Gutierre de Sotomayor, Maestre de Alcántara}

Como no podía ser de otra forma, la acción llevada a cabo por don Gutierre vino a cambiar bruscamente el signo de la situación. Rápidamente acudieron desde Cáceres el adelantado Pedro Manrique y el almirante Fadrique con sus tropas, pero Don Gutierre, temeroso de perder los beneficios que la captura habría de reportarle, no les permitió la entrada en la villa, alojándolos en el arrabal ${ }^{74}$. Puro formulismo, o continuación del plan, escribió a su tío dándole cuenta de la prisión del infante y de cómo, para su liberación, solicitaba la puesta en libertad suya, así como la del doctor Franco y el clavero. Desde Piedrabuena llegó, por medio del clavero, la respuesta del maestre: nunca había sido apresado, todo era una falsedad, demandándole soltase a don Pedro. La baza política que suponía el infante era demasiado valiosa como para dejársela arrebatar, y esto no estaba dispuesto

72 DEL PINO GARCÍA, p. 183.

${ }_{73}$ M. F. LADERO QUESADA, «La Orden de Alcántara en el siglo XV. Datos sobre su potencial militar, territorial, económico, y demográfico", En la España Medieval, II, pp. 499-542, p. 509. Véase el reciente estudio de MONTANA CONCHIÑA, José Luis de la, "La red comendataria alcantarina en el siglo XV», en Revista de Estudios Extremeños, Año 2008, Tomo LXIV, pp. 717-759.

${ }^{74}$ RADES Y ANDRADA, fol. 40, cit. por MUÑOZ DE SAN PEDRO, pp. 31-32, nota n.․46. 
a permitirlo, al menos, no antes de que el monarca se ratificase en las promesas realizadas por el doctor. El 10 de julio llegó Juan de Perea a Alcántara con cartas de creencia del rey, ofreciéndole dar el maestrazgo y todo aquello que su tío tenía situado en las rentas reales; y, aún más, perdonaría al maestre. Esto último, junto con la condición de que su tío quedase acomodado nos indica la preocupación que siempre mostró don Gutierre por su tío a quien realmente debía todo cuanto hasta en ese momento había sido ${ }^{75}$. Entre presiones, tanto por parte de su tío y el infante Enrique como por Juan II, trasladó al preso al castillo de Valencia de Alcántara, regido por don Gutierre de Raudona, persona de su total confianza. El maestre, enterado de ello, atacó la villa. Nada pudo hacer ante la defensa del comendador mayor, caballeros, y vecinos y moradores ${ }^{76}$. La llegada de las tropas del adelantado y del almirante pusieron en fuga a las tropas atacantes.

Las negociaciones entraron en su recta final. El embajador de Portugal, Pedro González Matalfaya propuso a don Álvaro de Luna la posible liberación del infante don Pedro a cambio de que el infante don Enrique entregase todas las villas y fortalezas que aún le obedecían ${ }^{77}$. El acuerdo definitivo llegaría en octubre: a cambio de Alburquerque, Azagala, Mayorga, Piedrabuena y Alconchel, la liberación del doctor Franco, y la promesa de abandonar posteriormente el reino de Portugal, Juan II entregaría al infante don Pedro. En Lisboa, tras cumplirse los pactos, embarcaron los infantes rumbo a Valencia, junto con la infanta doña Catalina, mujer de don Enrique, el obispo de Coria, don Martín Galos, y don Juan de Sotomayor, a pesar de la renta asignada de 4.000 florines y de la libertad para vivir en el reino ${ }^{78}$.

En el transcurso de los hechos, las cosas cambiaron en el maestrazgo. A mediados de agosto, reunido el Capítulo General de la orden en la fortaleza y convento de Alcántara, ciudad que había sido tomada por las fuerzas reales para su defensa y protección, se destituyó del cargo de maestre a don Juan de Sotomayor por el deservicio mostrado ante el rey, eligiendo por maestre a su sobrino don Gutierre $^{79}$. La elección fue confirmada por el papa Eugenio IV el 7 de diciembre ${ }^{80}$. El 21 de agosto el rey recibió la noticia estando en Villeruela ${ }^{81}$. El 17 de septiembre

75 De ahí la acusación que formuló Cola María Burzuto de notoria traición cometida por vos al maestre, lo qual hos avía criado e fecho mucho de mui poca cosa, en Colección, doc. 870, public. por CABRERA MUÑOZ, p. 383.

76 «al tiempo quel dicho Juan de Sotomayor vino e se quiso apoderar de la villa de Valençia, que es del dicho maestradgo, para se alçar e revelar con ella en mi deservicio, vos le resististes e fezistes resistir la entrada della e la defendistes e guardastes para mi serviçio, e los vecinos e moradores de la dicha viIla, así cristianos, como judíos e moros por vuestro mandato se mostraron lealmente a la dicha resistencia», Privilegio otorgado por Juan II a la villa de Valencia de Alcántara el 30 de septiembre de 1432 en Ciudad Rodrigo, B. AGS, Mercedes y Privilegios, leg. 4, doc. 41, Colección, doc. 873.

77 CARRILLO DE HUETE, p. 134.

78 MUÑOZ DE SAN PEDRO, p. 35, nota n. ำ53, con ref. a GIL DORREGARAY, Historia de las tres Órdenes de Caballería, t.l, p. 230.

79 CABRERA MUÑOZ, p. 91, nota n.44, con ref. a ALVAR GARCÍA DE SANTA MARÍA, p. 358.

80 Colección, doc. 875. No hay duda que quien estaba detrás de todo esto era no tanto el monarca como don Álvaro de Luna. GONZALO CHACÓN, pp. 450-451, lo deja muy claro en su crónica, «Pues menos es de dexar en olvido una tan grand dignidad como es la Caballería de la Orden e maestradgo de Alcántara, que por intercesión e a suplicación del Maestre nuestro fue dada a don Gutierre de Sotoma- 
fue recibido el nuevo maestre en la Corte, establecida en Ciudad Rodrigo y al día siguiente, después de la celebración religiosa, hizo juramento y pleito homenaje ante el rey de servirle fiel y lealmente, así como también por las fortalezas del maestrazgo, recibiendo de manos de éste el pendón de la orden.

\section{ANDADURAS EN LA CORTE. LA PARTICIPACIÓN EN LA POLÍTICA DE JUAN /I}

Los principales acontecimientos que marcaron la vida política castellana: levantamientos, rebeldías, bandos, partidos, cambio de fidelidades, conatos de bataIla, negociaciones..., se suceden a lo largo y ancho del período estudiado. ¿Qué papel jugó en todo ello el flamante maestre de Alcántara don Gutierre de Sotomayor?

Como se acaba de apuntar la captura del infante don Pedro supuso para don Gutierre de Sotomayor su ascensión al primer plano de la política castellana. Merced a esta actuación, llegó a ser considerado — según la opinión de Muñoz de San Pedro- como el segundo personaje en el reino de Castilla tras, por supuesto, el condestable don Álvaro de Luna ${ }^{82}$. Fue precisamente junto al Condestable, y lo que él venía a representar en el reino, con quien el maestre de Alcántara se alineó desde los primeros momentos; alianza que, como tendremos ocasión de comprobar, le reportó cuantiosos beneficios.

\subsection{La campaña de Granada}

La campaña llevada a cabo por el flamante maestre de Alcántara en tierras del reino granadino supuso la primera intervención de don Gutierre. Designado como Capitán de la Frontera de Écija tras el fallecimiento del adelantado Diego de Ribera, capitán hasta entonces, sustituyó con la gente de su casa a los hombres de armas del dicho adelantado, así como veinte lanzas de Lorenzo Suárez de Figueroa presentes en la dicha frontera ${ }^{83}$. Juan II ordenó a Suárez de Figueroa el traslado de sus tropas a Huéscar ${ }^{84}$.

Muñoz de San Pedro nos da una cifra para el ejército del maestre de ochocientos jinetes y cuatrocientos infantes ${ }^{85}$. Sabemos que no todo este contingente había sido levantado en el maestrazgo, ya que se habían incorporado tropas de

\footnotetext{
yor». Abundando en lo dicho, cuando el Papa Eugenio IV notifique a Juan II que ha atendido su petición sobre el maestrazgo de la orden de Alcántara, el 5 de enero de 1433, lo notificará igualmente a don Álvaro de Luna, en Colección, docs. 877 y 878.

81 CARRILLO DE HUETE, p. 135

82 MUÑOZ DE SAN PEDRO, p. 45

${ }^{83}$ Carta de Juan II a Lorenzo Suárez de Figueroa, 22 de noviembre de 1434, Colección, doc. 900.

84 Ibídem.

${ }^{85}$ Torres y Tapia da una cifra similar, siendo probablemente éste la fuente de Muñoz de San Pedro.
} 
Sevilla y es posible que también del señor de El Carpio, García Méndez de Sotomayor ${ }^{86}$.

La campaña fue un rotundo fracaso. Del repaso a la lista de personajes que murieron en la misma se deduce la entidad de la expedición, y nos ayuda en nuestro intento de profundizar en los posibles lazos que los unían al maestre ${ }^{87}$.

\subsection{Entrada en la estructura de relaciones de la corte: bandos, ligas, destierros}

A comienzos de 1437 se produjo la escisión entre los miembros de la oligarquía que ostentaban el gobierno de Castilla: el adelantado Pedro Manrique, el almirante don Fadrique y don Pedro de Stúñiga, criticaron abiertamente la política del condestable. El maestre de Alcántara, fiel al camino emprendido con los hechos acaecidos en 1432, permaneció en el partido del condestable. No tuvo que esperar mucho para demostrarlo. El 20 de agosto del año siguiente consiguió escapar de la prisión, a que había sido sometido por orden de don Álvaro, el adelantado Pedro Manrique. «El Maestre, pensando que pudiera ser útil, marchó a Medina del Campo, al frente de sus caballeros, para ponerse a las órdenes del Monarca y de Don Álvaro de Luna»88. Con la huida, la rebelión se extendió por todo el reino, sumándose a ella los principales linajes de la nobleza. Hay un hecho, sin embargo, que resulta cuanto menos curioso si nos atenemos al juego de alianzas existente. El 20 de febrero de 1439 el almirante Fadrique y el adelantado Pedro Manrique enviaron al monarca una carta en la que demandaban la salida de la corte del condestable, exceptuando de entre sus parientes e gentes, los condes de Haro e de Castro, e maestre de Alcántara, e obispo de Palencia, e doctor Periañes... ${ }^{89}$. ¿Esperaban con esta medida sumar partidarios a su causa 0 , al menos, no buscarse más enemigos? Tal disyuntiva (si realmente se dio) no pareció mostrarla el infante don Enrique. Enemigo acérrimo del maestre desde los días de la prisión de su hermano Pedro, su vuelta a Castilla en abril de 1439 le permitió, desde el primer momento, colocarse a la cabeza del partido hostil al condestable y, con ello, la oportunidad de saldar viejas cuentas ${ }^{90}$. El martes 26 de mayo envió una carta al condestable y al maestre, mediante la cual les fazía saber que de aqueste día en adelante alzaba la tregua e seguro que entre el infante e ellos avía, e que de ay adelante se guardase del, que do quiera que daño o mal pudiese fazer a ellos e a

86 1434, marzo, 28. Madrid, Colección, doc. 903.

87 En CARRILLO DE HUETE, pp. 199-200; MUÑOZ DE SAN PEDRO, p. 42 y nota n.ำ 71; TORRES Y TAPIA, p. 303, se puede ver el nombre de estos comendadores.

88 MUÑOZ DE SAN PEDRO, p. 45. TORRES Y TAPIA narra el suceso en los mismos términos, aunque comete una errata al decir el Maestre de Alcántara D. Juan de Sotomayor, p. 309.

89 CARRILLO DE HUETE, p. 259.

90 La Liga se había vuelto a restablecer a instancias del infante don Enrique en Renedo, poco antes de la conferencia que debía llevarse a cabo en dicho lugar. 
lo suyo que sopiesen que lo faría ${ }^{91}$. La mediación del rey impidió que el desafío pudiera realizarse ${ }^{92}$.

El segundo destierro del condestable, decidido en las conferencias de Castronuño en la segunda quincena de octubre de 1439, supuso también el repliegue de don Gutierre hacia las tierras del maestrazgo.

Hasta 1440 no va a reaparecer el maestre en escena ${ }^{93}$. Mientras don Álvaro organizaba su resistencia en Escalona, los principales clanes políticos de Castilla se incorporaban a la Liga. Un acontecimiento extraordinario fue aprovechado por el condestable para reforzar su posición. La muerte prematura del rey Duarte de Portugal dio paso a la entronización de un niño, hijo de la infanta Leonor de Aragón, que fue coronado como Alfonso V. La regencia, que debía recaer sobre ésta, le fue sustraída por el infante don Pedro, duque de Coimbra, hermano del difunto. A la protesta de los infantes de Aragón, sus hermanos, respondió el duque firmando una alianza con el condestable y con el maestre de Alcántara ${ }^{94}$. Para formalizarla, acudió el maestre a Escalona a la llamada de don Álvaro ${ }^{95}$. No defraudó el maestre la confianza que don Álvaro había depositado en él. Triunfantes la nobleza y los infantes - triunfo sancionado en las Cortes de Valladolid celebradas entre junio y septiembre de 1440-, una de sus primeras acciones fue tomar posesión de las villas y ciudades enajenadas a la corona - en virtud, recordemos, de la promesa de devolución de todo lo tomado o su equivalencia acordado en Castronuño $0^{96}$. Entre otras, Cáceres y Trujillo, destinadas, respectivamente, al príncipe don Enrique y a Pedro de Stúñiga, conde de Ledesma ${ }^{97}$. Ambas opusieron resistencia armada, para lo que contaron con la ayuda de don Gutierre de Sotomayor ${ }^{98}$. En el caso de Trujillo, el 15 de febrero de 1441, desde Ávila, Juan II, «...haciendo alusión a una carta que recibió de Diego de Orellana ordenaba al alcaide Gómez González de Carvajal, tras quitarle el pleito homenaje que tenía por él y su hijo el príncipe, que entregase el alcázar y fortaleza a su bien amado e leal caballero don Gutierre de Sotomayor, maestre de Alcántara, en cuyo poder debió quedar durante mucho tiempo" ${ }^{99}$.

91 CARRILLO DE HUETE, p. 287.

${ }_{92}$ MUÑOZ DE SAN PEDRO, p. 46, con ref. a Centón Epistolario, epístola LXXXI.

93 Durante ese tiempo que permaneció apartado de la corte, sus esfuerzos se centraron en los asuntos del maestrazgo. Entre otros, el comienzo de las obras del convento de la orden en Alcántara.

${ }^{94}$ SUÁREZ FERNÁNDEZ, Los Trastámaras de..., p. 164, nota n.ำ 56.

95 MUÑOZ DE SAN PEDRO, p. 46.

96 CARRILLO DE HUETE, p. 299.

97 La devolución de las antiguas propiedades conllevó una serie de permutas. Así, Pedro Ponce de León cedió Medellín, que volvió a manos del infante Enrique, a cambio de obtener Arcos con título de condado. El infante pidió que se le entregara Cáceres, pero la unión juramentada de la oligarquía cacereña impidió que Juan II la cediera, en previsión de males mayores. Como solución, Cáceres fue entregada al príncipe Enrique, a cambio de no enajenarla del patrimonio de la corona. A su vez el príncipe renunció a Trujillo, que fue cedida a Pedro de Stúñiga con título condal, y éste a la villa de Ledesma, que se entregó al infante de Aragón. DEL PINO GARCÍA, p. 186.

98 CARRILLO DE HUETE, p. 354.

99 DEL PINO GARCÍA, p. 82. La carta a la que se alude en Colección, doc. 930. 
La lucha entró en una fase más intensa a partir de 1441, y con ella la participación del maestre se agudizó. En los primeros días de enero el rey le comunicó el encargo de tomar posesión en su nombre de los términos de Puebla de Alcocer y Herrera (como muy bien apunta Cabrera Muñoz, hay que ver en estos acontecimientos el punto de partida más remoto en la formación del señorío de los Sotomayor), y ello como consecuencia de las graves afrentas infringidas por Toledo al rey. El 10 de enero, desde Torrijos, éste hizo saber a los concejos y oficiales de Puebla de Alcocer, Herrera y otros lugares de los montes propios de la ciudad de Toledo la ofensa sufrida, y la resolución que contra ello había tomado ${ }^{100}$. El maestre debió partir algunos días después, ya que el 9 de enero aún se encontraba en Alcántara confirmando sus privilegios a la villa de la Torre de don Miguel ${ }^{101}$. Pero la situación en Extremadura distaba mucho de estar tranquila. También a comienzos de año el rey había ordenado a Lorenzo Suárez de Figueroa la defensa de Badajoz ante cualquier ataque de los rebeldes ${ }^{102}$. El maestre de Alcántara se hallaba combatiendo en Mérida, hacia donde se dirigieron el infante don Enrique y el comendador mayor de Santiago, Lope de Stúñiga para presentarle batalla. En un intento por evitar el choque directo, Suárez de Figueroa escribió a ambas partes, poniéndose a su disposición como mediador en el conflicto ${ }^{103}$. Por la respuesta dada por el infante podemos colegir que el enfrentamiento no llegó a producirse. El que sí se produjo fue el que tuvo lugar un mes después entre don Gutierre y Alfonso Enríquez, hijo del almirante. Así, el lunes 10 de abril, «...legaron nuebas al Rey del Maestre de Alcántara, don Gutierre de Sotomayor, en como ovo topamiento con Alfonso Enrríquez en un lugar que llaman Arroyo de Molinos, una legua de Montánchez; e desvarató el maestre al Alfonso Enrríquez, e prendióle noventa escuderos, e tomole ciento catorce caballos e arneses, e fuyó Alfonso Enrríquez» 104.

Si en los meses de febrero y marzo las victorias se decantaron por el bando nobiliario (Rodrigo Manrique y Pedro de Quiñones atacaron Maqueda e Illescas; Gabriel Manrique e Iñigo López de Mendoza se apoderaron de Alcalá de Henares; Juan de Tovar y Ruy Díaz de Mendoza ocuparon Sepúlveda, Ayllón y Riaza), en el curso del mes de abril la segunda fase de la guerra pareció a punto de darle la victoria a don Álvaro, con las victorias en las afueras de Escalona y en Torote sobre los capitanes del infante don Enrique, el 5 y 6 de abril respectivamente ${ }^{105}$.

El efecto de las victorias espoleó a Juan II. El 19 de mayo de 1441 se apoderó de Medina del Campo, si bien la fortaleza de la Mota, en donde se había refugiado Fernando de Rojas, hijo del conde de Castro, tardó algunos días en rendirse. El 27 de mayo el rey de Navarra sentó sus reales en la Zarza, a mitad de camino entre

100 Colección, doc. 929. En abril, La Puebla de Alcocer fue declarada por el rey villa en sí, dotándola de jurisdicción propia apartada de la de Toledo, en CABRERA MUÑOZ, p. 112 y nota n. 109 .

101 Inserto en documento de Gómez de Cáceres de 2 de julio de 1458, Colección, doc. 928.

102 DEL PINO GARCÍA, p. 187, nota nํ 113 con ref. a F. MAZO ROMERO, El condado de Feria, pp. 181-182.

103 Conservamos la enviada al maestre y comendador mayor de Santiago, Colección, doc. 931.

104 CARRILLO DE HUETE, p. 392.

105 SUÁREZ FERNÁNDEZ, Los Trastámaras en..., p. 168. 
Medina y Olmedo. Avisado por el condestable, don Gutierre de Sotomayor partió hacia Escalona. La noticia del cerco al que los infantes tenían sometido al rey hizo que «...el Condestable, como bueno e leal vasallo, juntó luego su gente, e juntó luego consigo al arçobispo de Toledo su hermano, e a don Gutierre, maestre de Alcántara, e vino todo a andar a Medina del Campo ${ }^{106}$. El 2 de junio todos los rebeldes acudieron a poner su real sobre Medina del Campo. Acompañado de Luis Méndez de Sotomayor, salió el rey don Juan a esperar al rey de Navarra e infante don Enrique cerca de Carrioncillo ${ }^{107}$. Entre el 2 y el 8 de junio se produjeron entre ambos bandos intermitentes escaramuzas. La noche del 8 «...llegaron a Medina don Álvaro de Luna, e el arçobispo de Toledo su hermano, e don Gutierre de Sotomayor, maestre de Alcántara, con mill y seiscientos hombres de armas e ginetes ${ }^{108}$. La llegada de las fuerzas sirvió para reforzar a tiempo las tropas realistas, lo que permitió a éstas algunas salidas contra los infantes que continuaban cercando la plaza, pero no la tan soñada batalla que buscaba don Álvaro y que una negociación de última hora impidió ${ }^{109}$. En una de estas salidas, el rey «...mandó armar toda la gente que estava en la villa, e salió a la plaza con fasta mill hombres de armas e ginetes, e con él el su condestable, e el arçobispo de Sevilla don Gutierre, e el conde de Alba, e el maestre de Alcántara, e otros caballeros» ${ }^{110}$. La destacada intervención de don Gutierre y sus tropas en ésta y otras escaramuzas se vio empañada por el apresamiento, el 15 de junio en la escaramuza en los molinos de viento, camino de Tordesillas, de García Méndez de Sotomayor, comendador de la orden, así como por el asalto y la captura, un día después, del recuaje del condestable, del arzobispo su hermano y del maestre de Alcántara, llevado a cabo por Juan de Navarra ${ }^{111}$.

El 18 de junio, por fin, don Álvaro consiguió del Consejo una decisión favorable a la guerra contando, con el decidido apoyo que le prestaron el conde de Alba y el maestre de Alcántara ${ }^{112}$. El desenlace a la tensa situación llegó de forma inesperada. Un golpe de sorpresa vino a darse en favor del rey de Navarra cuando sus partidarios le abrieron las puertas de la ciudad en la noche del 28 al 29 de junio ${ }^{113}$. Bien por propia iniciativa o por consejo del rey, lo cierto es que el condestable huyó hacia Escalona seguido por sus más fieles partidarios, el arzobispo de Toledo su hermano y el maestre de Alcántara ${ }^{114}$. De esta forma el poder volvió de nuevo a manos de los infantes que decretaron el exilio del condestable y la expulsión de la Corte de todos sus hombres.

106 GONZALO CHACÓN, p. 153.

107 CARRILLO DE HUETE, p. 410.

108 Ibídem, p. 411.

109 Cuando el rey iba a atacar, la reina Leonor de Portugal, hermana de los infantes, se interpuso llorando, de modo que su primo dio marcha atrás en sus propósitos.

110 CARRILLO DE HUETE, p. 412.

111 TORRES Y TAPIA, pp. 312-313.

112 CARRILLO DE HUETE, p. 414.

${ }_{113}$...día de S. Pedro y S. Pablo el Rey de Navarra y los caballeros que seguían su voz entraron y se apoderaron de Medina por trato doble de algunos de sus vecinos, D. Álvaro de Bracamonte y Fernando Rejón, criado del Rey de Navarra., en TORRES Y TAPIA, p. 313.

114 MUÑOZ DE SAN PEDRO, p. 47 y nota n. 84. 
No sabemos el tiempo que permaneció el maestre en Escalona, pero en marzo de 1442 lo encontramos en Llerena. Desde aquí, el día 2 nombró a Iñigo López de Ágreda, su sobrino, como alcalde mayor de Morón, cesando en el mismo a Fernando Ponce de León ${ }^{115}$. ¿A qué obedeció la sustitución? Si bien Torres y Tapia no supo encontrar la causa de la misma, ésta puede encontrarse en el ajuste de cuentas iniciado por don Gutierre con aquéllos que propiciaron su vergonzosa salida de Medina. Si entonces fue el hijo del conde de Arcos el primero en sufrir las represalias, más tarde sería el conde de Ledesma, don Pedro de Stúñiga, a quien impediría don Gutierre la dominación sobre Trujillo ${ }^{116}$.

Lo que no acababa de cesar era la crisis política castellana que, lejos de arreglarse, entraba en su fase más aguda. La consecuencia más inmediata de Rámaga (9 de julio) fue la instalación de un hijo bastardo del rey de Navarra, Alfonso, a la cabeza de la orden de Calatrava. Tras la muerte del maestre don Luis de Guzmán, dos candidatos pretendían la dignidad maestral: el clavero Fernando de Padilla, apoyado por la mayor parte de los caballeros, y el comendador mayor, Juan Ramírez de Guzmán, sostenido por el príncipe Enrique. A la orden real a los comendadores de Calatrava para que procediesen a la elección como maestre de Alfonso, hijo bastardo del rey de Navarra, se opuso el clavero. El infante don Enrique sitió y tomó la fortaleza de la orden, muriendo en el asedio el propio Fernando de Padilla. Fracasó también la candidatura del comendador mayor, Juan Ramírez de Guzmán, siendo finalmente designado Alfonso mediante una bula de Eugenio IV, en contra de la voluntad de los comendadores, el 4 de septiembre de $1443^{117}$. Estas circunstancias trajeron a su vez la alianza de Juan Ramírez de Guzmán, que siguió utilizando el título de maestre de Calatrava, con el maestre de Alcántara, al prestar su ayuda a don Gutierre de Sotomayor frente al infante don Enrique.

\subsection{La defensa de Sevilla}

La intervención en las luchas por el maestrazgo de Calatrava proporcionó la ocasión al infante don Enrique de actuar en Andalucía, donde pretendía ejercer su hegemonía sobre los nobles andaluces. Contando con la ayuda del conde de Arcos, ocupó Córdoba, Carmona y Alcalá de Guadaira, desde donde se dispuso a atacar Sevilla. Como ya apuntó Cabrera Muñoz, la defensa de Sevilla y la liberación posterior de Córdoba, Carmona y Alcalá de Guadaira constituye, sin lugar a dudas, el más meritorio de los servicios prestados a Juan II por el maestre de Alcántara. Fue en esta ocasión, además, cuando la iniciativa personal y las dotes de organización del maestre se pusieron a prueba. De esa acción sola derivaron,

115 Colección, doc. 934.

116 Años después, el maestre rectificó lo obrado contra Fernando Ponce, concediéndole el perdón junto con alguno de sus allegados. TORRES Y TAPIA, p. 318.

117 SUÁREZ FERNÁNDEZ, Los Trastámaras en..., p. 177, y nota n.ำ 120. 
por otra parte, las mercedes regias que pusieron en manos de don Gutierre la parte más importante de sus futuros señoríos, aquella que constituyó el núcleo esencial y permanente en los estados de los futuros condes de Belalcázar ${ }^{118}$.

El hecho de que el infante don Enrique contase con dos mil hombres de armas hizo ver la necesidad de allegar más recursos humanos, de ahí que Sevilla también solicitase la ayuda, además de don Gutierre, del duque de Coimbra. Es decir, fue el concejo sevillano quien solicitó la ayuda. En esos momentos, al frente del concejo se hallaban el conde de Niebla y el adelantado Perafán de Ribera, ambos decididos partidarios de don Álvaro de Luna. La unión de don Gutierre con el conde de Niebla iba más allá de la meramente política: don Gutierre había engendrado un hijo, Alfonso, con doña Leonor de Guzmán, hija del conde de Niebla ${ }^{119}$. Por lo tanto, el que se solicitase la ayuda del maestre de Alcántara respondía tanto a la pertenencia de ambos al mismo bando político, el del monarca, como a los lazos reales de parentesco que existían entre maestre y conde.

La defensa de Sevilla, así como la recuperación de Carmona, Alcalá y Córdoba, sin ser obra personal de Gutierre de Sotomayor, fue una empresa en la cual el maestre de Alcántara asumió el papel de protagonista. Él fue indudablemente quien llevó el peso en la organización militar de la campaña puesto que fueron las milicias de la orden, unidas por las enviadas por el regente de Portugal, de las que se hizo cargo, las que constituyeron el núcleo del ejército. Junto a Gutierre de Sotomayor, aparece la figura de Juan Ramírez de Guzmán, maestre nominal de Calatrava, desprovisto seguramente de una tropa propia. Sólo el conde de Niebla, cuyo papel fue fundamental, sobre todo en la organización de la defensa de la ciudad y principalmente en el largo mes de espera que aquélla hubo de afrontar antes de la llegada del ejército liberador, puede equipararse en esta ocasión a don Gutierre. Ambos, por lo demás, fueron los máximos beneficiarios del reparto que siguió a la campaña: el conde de Niebla recibió entonces el título ducal de Medina Sidonia; para el maestre de Alcántara se suceden las diferentes mercedes que van a hacer posible la adquisición y disfrute de un señorío laico al margen de la jurisdicción eclesiástica: Gahete, Hinojosa y Puebla de Alcocer. En otro lugar de este trabajo trataremos más detenidamente sobre estas cuestiones ${ }^{120}$.

\subsection{Los sucesos de Murcia}

El 10 de mayo recibió don Gutierre la orden del rey de restituir Moguer a doña María Portocarrero ${ }^{121}$. Puede que la falta de liquidez para llevar a cabo esta empresa fuese la causa de que solicitase a Sevilla, el 12 de junio, un permiso para sa-

118 CABRERA MUÑOZ, p. 115.

119 1437, septiembre, 4. Medina del Campo. Juan II legitima «en lo tenporal» a Alfonso de Sotomayor, hijo del maestre de Alcántara, Gutierre de Sotomayor. Colección, doc. 917.

120 Vid. 3.1. Concesión de mercedes.

121 Colección, doc. 940. 
crificar en las carnicerías de la ciudad mil carneros y cierto número de reses vacunas que había traído de sus tierras, pero lo cierto es que a finales de mes aún permanecía en Sevilla. Allí recibió una carta del príncipe don Enrique encargándole a él, al maestre de Calatrava, al conde de Niebla y al adelantado Perafán de Ribera que marchasen en persecución del infante don Enrique ${ }^{122}$.

Comenzado el otoño de 1444, el ejército real, mandado por el condestable y el príncipe, cruzaba los puertos para despejar los maestrazgos de Santiago y Calatrava, que apenas el infante don Enrique intentó defender. Quería, en cambio, crear en Murcia puntos de apoyo permanentes aprovechando las discordias que allí existían. Muerto el adelantado mayor, Alonso Yáñez Fajardo, su hijo Pedro le había sucedido en el adelantamiento. Pero su primo Alfonso, alcaide de Lorca, le disputó la primacía del reino. El Bravo buscó el apoyo de los infantes de Aragón y don Enrique halló asilo en Lorca. Hasta allí se desplazó don Gutierre de Sotomayor, acompañado por Lorenzo Suárez de Figueroa, seguramente con la intención de sumar sus efectivos a los del condestable ${ }^{123}$. La última semana de octubre de 1444 don Álvaro de Luna y el príncipe cercaron Lorca sin éxito, regresando de nuevo al interior del reino ante la anunciada invasión aragonesa.

Firmadas treguas por cinco meses, éstas expiraron a finales de febrero ${ }^{124}$. Avisado don Gutierre, volvió a Extremadura a finales de 1444. Desde Zalamea, ya en 1445, se dirigió a Guadalupe para entrevistarse con el Rey quien, en premio a sus méritos, el 7 de abril le hizo merced del Señorío de la Puebla de Alcocer, con facultad para fundar mayorazgo sobre esta villa y las de Gahete e Hinojosa, que ya poseía. El maestre, a la espera del aviso de incorporación a las tropas reales, partió a Alcántara ${ }^{125}$.

\subsection{Olmedo}

La situación se precipitó cuando se supo en Medina —antes incluso de que concluyesen las treguas-, que Juan de Navarra se había introducido en Atienza, donde le había acogido Luis de la Cerda, conde de Medinaceli, que estaba allí por frontero precisamente contra el infante llegado. Uniéndose posteriormente con su hermano Enrique, que venía desde Lorca atravesando la Mancha, y ante la negativa de Alfonso $\mathrm{V}$ de intervenir en el conflicto, los infantes se establecieron el 24 de marzo en Olmedo. Ese mismo día el séquito regio se instaló en Arévalo. Antes de entrar a combatir, se entablaron negociaciones. Los infantes y sus parciales pi-

122 El que las cartas procedan del príncipe obedece al hecho de que, preso el rey en Portillo, el heredero ejerció durante un tiempo las funciones de gobierno, estableciendo para ello su base de operaciones en Ávila.

123 Colección, doc. 943.

124 Las treguas fueron firmadas por el rey Juan II y por el rey de Navarra el 25 de septiembre de 1444 , en SUÁREZ FERNÁNDEZ, Los Trastámaras en..., p.181.

125 MUÑOZ DE SAN PEDRO, pp. 53-54. 
dieron al monarca la restitución de todo lo confiscado. Don Álvaro, el 15 de mayo, hizo ratificar ante los procuradores reunidos en las tiendas de paño en la llanura frente a los muros de Olmedo, la Ley XXV de las Partidas, acerca del poder real ${ }^{126}$. A pesar de su firme actitud y determinación, don Álvaro hizo concebir esperanzas a los infantes de que accedería a sus peticiones para evitar la batalla. Todo ello con la finalidad de ganar tiempo esperando la llegada de don Gutierre de Sotomayor con sus vasallos. Sin duda, un aporte que vendría a equilibrar las fuerzas reales con las que poseía el rey de Navarra. La batalla, por lo tanto, «...se dilató fasta el seteno día, que llegó al rreal el maestre de Alcántara con quinientos rocines, ginetes doscientos e trescentos honbres de armas, muy avantajados. La qual venida avaxó mucho el orgullo que tenía el rrey de Navarra e infante e los caballeros de su opinión» ${ }^{127}$.

La batalla se produjo inesperadamente, el 19 de mayo de 1445, consecuencia de la generalización de una escaramuza mantenida entre el príncipe don Enrique y Rodrigo Manrique. En el transcurso de ésta, los de Olmedo salieron en su persecución, mandando entonces el rey formar sus batallas. Cuando quedaban dos horas de sol, y las tropas reales regresaban a su campamento después de haber esperado la salida del grueso del ejército, comenzaron a salir de Olmedo el rey de Navarra y sus partidarios, con sus batallas ordenadas. Dando la vuelta por orden de Juan II, el «...condestable avanzó en vanguardia, con ochocientos hombres escogidos, quedando frente a las tropas del Infante Don Enrique, del Almirante y del Conde de Benavente; a la derecha, como refuerzo, tenía al Conde de Alba y a Don ínigo López de Mendoza. En el ala izquierda iban las tropas del Príncipe de Asturias, mandadas por su favorito, don Juan Pacheco, luego Marqués de Villena, teniendo a su lado, como base fundamental de protección, a Sotomayor. Frente a éstos se situaron el Rey de Navarra y el Conde de Castro. La retaguardia quedó a cargo del Monarca castellano, al que acompañaban los Condes de Haro y de Ribadeo. Reservándose el mando supremo de todas sus fuerzas, don Gutierre las dividió en seis unidades, poniendo al frente de cada una de ellas a caballeros alcantarinos...» ${ }^{128}$. La actuación de don Gutierre de Sotomayor en el desarrollo de la batalla parece fue de gran valía, como se encargan de recoger los diferentes cronistas del período ${ }^{129}$. Actuación que le mereció nuevos beneficios reales, amén de la consolidación de los ya existentes. Así, en el reparto de los bienes confiscados

\footnotetext{
126 SUÁREZ FERNÁNDEZ, Los Trastámaras en..., p. 183. Un trabajo sobre lo que significaron las Cortes de Olmedo en cuanto a la enunciación de los principios básicos de la realeza, en J. M. NIETO SORIA, «La Avisación de la Dignidad Real (1445), en el contexto de la confrontación política de su tiempo», en J. M. - SOTO RÁBANOS (coord.), Pensamiento Medieval Hispano. Homenaje a Horacio Santiago Otero. I, CSIC, Madrid, 1998, pp. 405-431.

127 CARRILLO DE HUETE, pp. 461-463. En MUÑOZ DE SAN PEDRO, p. 55, notas n. $94-98$ se recogen los testimonios cronísticos en cuanto a lo que supuso la llegada del maestre de Alcántara cara a su intervención en la batalla de Olmedo.

128 MUÑOZ DE SAN PEDRO, pp. 56-57.

129 Ibídem, pp. 57-58 y notas n. ํ 103-107.

130 CARRILLO DE HUETE, p. 468.
} 
a los infantes, el maestre de Alcántara recibió la villa de Alconchel, próxima a la frontera de Portugal ${ }^{130}$.

El desenlace de la batalla de Olmedo trajo consecuencias funestas para el partido encabezado por los infantes, suponiendo para éstos su expulsión definitiva del reino y la confiscación de todos sus bienes ${ }^{131}$.

La apresurada fuga del príncipe heredero junto con su favorito Juan Pacheco vino a oscurecer el panorama. Ésta se produjo a los pocos días de la victoria: desde Simancas, donde se hallaba el real, se trasladó el príncipe a Segovia. En su búsqueda mandó el rey al maestre de Alcántara con órdenes explícitas de llevarlo a su presencia incluso, si fuera menester, por la fuerza ${ }^{132}$. Fue imposible para don Gutierre alcanzar al príncipe quien, pasando rápido por Santa María de Nieva, consiguió encerrarse en Segovia, por lo que regresó el maestre al lado del monarca.

\subsection{Etapa de consolidación}

Con la nueva etapa que se inició tras la batalla de Olmedo, el ascendiente y la posición alcanzados por don Gutierre quedaron definitivamente consagrados. A lo acontecido hasta el momento, años de participación activa en situaciones difíciles para la monarquía de los que derivaron los mayores beneficios, el maestre siguió «sumando" en su particular carrera hacia el logro de sus objetivos. Servicios a la monarquía, que es tanto como decir a don Álvaro de Luna, enlaces matrimoniales, política familiar..., son aspectos que le reportaron una equiparación, tanto económica como social, con las grandes familias de la nobleza. Por lo pronto, don Gutierre se convirtió en uno de los grandes personajes de la corte que acompañaron al rey allá donde éste fuese.

Salido el infante don Pedro del reino, se trasladó la corte a Burgos y de aquí a Ávila, donde habían sido convocados los trece electores santiaguistas para elegir maestre a don Álvaro. La elección del condestable supuso, como contrapartida a los intereses del príncipe Enrique, el que se eligiese a Pedro Girón, hermano de Juan Pacheco, como maestre de la orden de Calatrava ${ }^{133}$. La Corte se desplazó a San Martín de Valdeiglesias y de aquí partió a Talavera camino de Extremadura con el objetivo, por parte del monarca, de entregar las villas que habían sido del infante don Enrique. Una vez en Cáceres, confirmó la donación de la villa a su hijo el príncipe. El siguiente destino fue Alburquerque, defendida por Fernando Dávalos, el cual se negó a entregar la plaza. Para rendirla, el rey demandó tropas a Lorenzo Suárez de Figueroa, señor de Zafra, al maestre de Alcántara, y a los concejos

131 El infante don Juan se refugió en su reino mientras que el infante don Enrique murió poco después en Calatayud, como consecuencia de las heridas recibidas en el curso de la batalla.

132 Crónica de Juan II, p. 630.

133 PORRAS ARBOLEDA, p. 251. 
de Trujillo, Mérida y Cáceres. Una vez rendida, la ciudad fue entregada a don Álvaro. No así su fortaleza, que fue entregada posteriormente junto con la de Azagala ${ }^{134}$. Según Muñoz de San Pedro, la mayor parte del éxito de estas empresas correspondió al Maestre.

Tras pasar unos días en Alburquerque, la corte se trasladó a Badajoz para entregar a Juan Pacheco las villas de Salvatierra, Villanueva de Barcarrota y Salvaleón. Pese a la inicial resistencia de la ciudad, finalmente cedió a la enajenación. También tuvo el rey problemas a la hora de entregar Alconchel. Destinada a Don Gutierre, su castillo se hallaba rebelado contra el monarca. Para reducirlo, el 5 de octubre escribió Juan II a las villas y lugares próximos demandándoles su ayuda, en personas y armas, en favor de Lorenzo Suárez de Figueroa, a quien había encomendado su recuperación ${ }^{135}$.

No fue ésta la única donación que recibió el maestre de Alcántara. El 20 de mayo, justo un día después de la batalla de Olmedo, obtuvo del rey una cédula en la cual se ordenaba proveer en don Fernando de Sotomayor, hermano pequeño del maestre, el obispado de Coria, vacante por la muerte de su titular ${ }^{136}$. Parece ser que las disposiciones nunca llegaron a cumplirse. Fue cuando, estando el rey por aquellas tierras con la intención de exigir precisamente su cumplimiento, se presentó en Coria Lorenzo de Godoy, escudero y criado de don Gutierre de Sotomayor. Éste presentó una nueva provisión firmada por Juan II el 27 de octubre de 1445 en Medellín, comunicando el postulado como obispo de Coria de don Fernando de Sotomayor ${ }^{137}$. Pero la Santa Sede ya había hecho su designación en don Alfonso Enríquez, poniendo el Papa interdicto a la Corona de Castilla, en 1446, con el fin de que se le diese la posesión. Eugenio IV, ante la resistencia del cabildo de Coria a aceptar a Alfonso Enríquez como obispo, y del maestre y algunos comendadores de Alcántara a reconocerle sus derechos, confirmó, el 18 de julio de 1446, las sentencias de excomunión y entredicho dictadas por sus delegados, así como los efectos que dichas penas conllevaban ${ }^{138}$. Al fin y a la postre, don Fernando de Sotomayor se quedó sin ser obispo, obteniendo en compensación la propiedad de Botua ${ }^{139}$.

Al alejarse el rey, dejó al maestre por Gobernador de Cáceres, Trujillo y toda Extremadura ${ }^{140}$. Una vez don Gutierre se vio libre de tareas cortesanas, el 12 de enero de 1446 tomó posesión de La Puebla, confirmándole a ésta sus privilegios $^{141}$. El 20 de febrero Juan II le dio licencia y facultad para reparar y edificar el

134 Ambas fueron entregadas por Dávalos una vez el rey le situó en su Hacienda una renta similar a la que recibía por ambas alcaidías. Ibídem, p. 253.

135 Colección, doc. 950.

136 MUÑOZ DE SAN PEDRO, p. 63.

137 Colección, doc. 951.

138 Colección, doc. 957.

139 MUÑOZ DE SAN PEDRO, p. 63.

140 TORRES Y TAPIA, p. 325.

141 Cit. en CABRERA MUÑOZ, p. 145, nota n. 46.

142 Colección, doc. 953. 
castillo existente a petición del mismo don Gutierre, sabedor de la oposición que despertaría la ocupación de la villa ${ }^{142}$. El propio rey tuvo que escribir desde EscaIona a la ciudad de Toledo, ordenándoles que cumpliesen la donación que de La Puebla había hecho al maestre, y que no hiciesen movimientos ni innovaciones sobre ella ${ }^{143}$.

Vuelto de Extremadura el monarca se aposentó en Toledo, destituyendo de las tenencias del alcázar y las fortalezas de la ciudad a Pedro López de Ayala (autor de anteriores agravios), y encomendando la guarda de los castillos a Pedro Sarmiento, repostero mayor, y personaje adicto a don Álvaro de Luna. La sustitución ahondó la brecha abierta entre los dos nuevos bandos en que quedó dividido el reino poco después de la batalla de Olmedo: el de don Álvaro de Luna y el que comenzó a encabezar el príncipe don Enrique. Después de un nuevo conato de batalla, las cosas volvieron a su cauce con la Concordia de Astudillo, el 14 de mayo de $1446^{144}$. En este ambiente de alianzas y posicionamientos debemos situar la alianza matrimonial proyectada por don Gutierre en 1446, firmando capitulaciones con Pedro de Stúñiga, conde de Plasencia, y con su hijo Álvaro, el futuro duque de Arévalo, para el matrimonio entre la hija de éste último, Elvira, y Alfonso de Sotomayor. De esta forma, entró en la órbita de una de las familias más ilustres de Castilla, con extensas posesiones en Extremadura próximas a las suyas ${ }^{145}$.

El 22 de julio de 1447 tuvo lugar en Madrigal de las Altas Torres el matrimonio entre Juan II y la infanta Isabel de Portugal. La presencia de don Gutierre como «principal» en tan magno acontecimiento es descrita por Muñoz de San Pedro como la culminación de su representación cortesana ${ }^{146}$. El rey le concedió nuevas villas y le amplió las facultades para fundar mayorazgos en sus villas de Puebla de Alcocer, Gahete e Hinojosa ${ }^{147}$. Una vez terminadas las fiestas se dirigió la corte a Aranda de Duero, camino de Soria, donde se esperaban embajadores de Aragón para tratar de poner paz entre los reyes de ambos reinos. Desde Aranda envió el rey al maestre de Alcántara con gente de armas a la ciudad de Soria, probablemente como avanzadilla, con la intención de asegurar la ciudad y defender la frontera, ya que a mediados de agosto corrían rumores de una próxima invasión aragonesa. A primeros de septiembre llegaron rey y condestable a la cabeza de 3.000 hombres de armas. Una vez en la villa los nuevos reyes, la ciudad fue entregada a Isabel ${ }^{148}$. Aquí consiguió del monarca, el 30 de septiembre, que el ba-

143 CABRERA MUÑOZ, p. 396.

144 SUÁREZ FERNÁNDEZ, Los Trastámaras en..., p. 190.

145 Las capitulaciones podemos leerlas en CABRERA MUÑOZ, pp. 390-396.

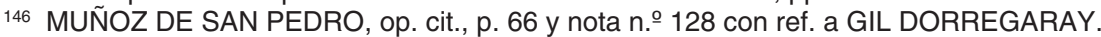

147 Antes de que se produjese el feliz acontecimiento, el 20 de mayo en Arévalo, mientras Juan II convocaba sus tropas en un nuevo episodio de las discordias existentes entre el monarca y su heredero, le fue confirmada a don Gutierre La Puebla de Alcocer mediante privilegio rodado. AGS, Patronato Real, leg. 58, fol. 35, cit en MUÑOZ DE SAN PEDRO, p. 67. La facultad para crear mayorazgos en sus villas de Puebla de Alcocer, Gahete e Hinojosa, para sus hijos, a los que legitimaba y capacitaba para recibirlos, fue otorgada el 31 de agosto de 1447 en Madrigal, Colección, doc. 959.

148 1447, septiembre, 9, cit. en SUÁREZ FERNÁNDEZ, Los Trastámaras en..., p. 192, nota n. 27. 
chiller Piedrafita fuera el encargado de proceder al deslinde y amojonamiento de los términos de Puebla de Alcocer, con el fin de evitar disturbios, apartándolos de los de Toledo ${ }^{149}$. Desde allí, en diciembre, el maestre se dirigió a las tierras de su maestrazgo ${ }^{150}$.

El 21 de enero de 1448 el rey de Navarra se lanzó a la ofensiva ocupando Santa Cruz de Campezo. La situación era un tanto confusa, no ya solamente por lo que acaecía en el exterior, sino por la propia situación interna. Como apunta Suárez Fernández, la política se había reducido a pactos entre personas. Prueba de ello, las múltiples confederaciones que se realizaron a lo largo y ancho del reino posicionándose por uno u otro partido. Entre ellas, la firmada por don Juan Guzmán, duque de Medina Sidonia, don Juan Ponce de León, conde de Arcos, Perafán de Ribera, adelantado mayor de Andalucía, don Pedro de Guzmán, alcalde mayor de Sevilla, y Alfonso de Velasco, veinticuatro de la dicha ciudad, el 23 de febrero en Sevilla, para guardar toda vía e sobre todas cosas el servicio del dicho Rey nuestro señor e del señor príncipe su fijo, nuestro señor e la honra e estado del señor don Álvaro de Luna maestre de Santiago, condestable de Castilla ${ }^{151}$. Entre los amigos a guardar, el maestre de Alcántara, don Gutierre de Sotomayor.

Los últimos meses de 1448 y los primeros de 1449 vieron renacer con nuevos aires los intentos de la oposición por desbancar de su puesto a don Álvaro. Las hostilidades se reanudaron en la frontera aragonesa a finales de año. En Murcia, los partidarios de don Álvaro acabaron por perder el control del reino, convirtiéndose a partir de entonces en base de operaciones de los aragoneses; incluso en Sevilla hubo tumultos y levantamientos. El 18 de diciembre, la fuga del conde de Benavente de Portillo vino a añadir un nuevo problema. La sublevación de Toledo, el 26 de enero del año siguiente, consecuencia del cobro de un empréstito para hacer frente a la amenaza de un ataque aragonés (se produjo en febrero), fue vista por muchos como la puntilla del condestable ${ }^{152}$. La rebelión de Toledo cambió de signo cuando en abril se colocó, a la cabeza de la misma, Pedro Sarmiento. Acusando de tiranía al condestable, exigió ciertas garantías al rey para permitirle la en-

149 CABRERA MUÑOZ, p. 149. La sentencia fue promulgada el 28 de noviembre de 1447, en La Puebla de Guadalupe (contiene además otros documentos sobre la donación a Gutierre de Sotomayor de Puebla de Alcocer y otro aspectos del proceso), Colección, doc. 961 . El 27 de mayo de ese mismo año Piedrafita ya había dado sentencia sobre el deslinde de términos de Hinojosa y Gahete, con un resultado muy favorable a don Gutierre.

150 Crónica de Juan II.

151 I. PASTOR BODMER, Grandeza y tragedia de un válido. La muerte de don Álvaro de Luna. Madrid, 1992, vol. II, pp. 216-218.

152 Emilio Cabrera ha visto, como una de las causas del levantamiento de Toledo, el despojo sufrido por la ciudad a favor de don Gutierre. Precisamente el año anterior, concretamente de abril a julio de 1448, se produjo el deslinde de términos de La Puebla de Alcocer, llevado a cabo por el bachiller Piedrafita (La ocupación de la misma la había hecho don Gutierre a comienzos de 1446). Ese mismo año, el 14 de octubre, se había dado sentencia contra el arzobispado de Toledo por intromisión en posesiones reivindicadas por el maestre, Colección, doc. 952. Con ello Toledo perdió no sólo La Puebla, sino también sus dehesas y parte de su territorio. La recaudación del empréstito vino a coincidir en un momento, por consiguiente, en que Toledo había perdido una fuente importante de sus ingresos. CABRERA MUÑOZ, p. 149. 
trada; garantías a las que no accedió don Juan, asentando su real el 8 de mayo frente a la Puerta de la Bisagra. Para atajar en lo posible la rebelión, «...don Álvaro de Luna, maestre de Santiago, ovo de concertar vista con don Gutierre de Sotomayor, maestre de Alcántara, e fechas sus vistas concertáronse en una voluntad»153. De esta forma hicieron frente a la ciudad, haciendo correrías por los alrededores, si bien no consiguieron entrar en ella. En el verano, como premio a sus servicios, el rey le hizo merced del lugar de Milagro, en el cual, junto con Bélmez (en Córdoba), situó una merced de cuatrocientos vasallos que acababa de otorgarle; a ello sumó la promesa de completar esa cifra con la concesión de otro lugar del reino de Toledo, caso de que la población de las citadas localidades fuese menor ${ }^{154}$. Unos días después, sin embargo, Juan II dejó en suspenso el disfrute de la merced anterior estableciendo que el título de la misma debía tenerlo en depósito, durante diez meses, el prior del monasterio de Guadalupe; si pasado dicho plazo no había entregado el rey a don Gutierre los 400 vasallos en lugar distinto, Bélmez y Milagro pasarían a formar parte de sus señoríos. También le prometió que, si esto último llegaba a producirse, le haría igualmente merced de los términos de Espiel, que él le había pedido por hallarse comprendidos en medio de los logares de Bélmez, junto a los de Hinojosa y Bélmez ${ }^{155}$. Meses antes de cumplirse el plazo, el 20 de octubre, Juan II le dio la villa de Medellín con su castillo, términos, jurisdicción..., en compensación de los 400 vasallos de Bélmez y Milagro prometidos anteriormente. En la fecha citada, la villa era del príncipe don Enrique, por lo que la concesión era transitoria - desde la fecha de otorgamiento hasta el día de Navidad - hasta tanto el rey no pudiera obtener la villa de su hijo; caso de no ser posible esto último, Juan II cumplimentaría la prometida merced de los 400 vasallos localizándolos en Fuenteovejuna, con el fin de que los añadiese don Gutierre a los que ya poseía en la villa, al tiempo que prometía concederle el lugar de Bélmez ${ }^{156}$. Pasados unos meses, la merced de Medellín quedó sin efecto, pero el 8 de marzo de 1450 el maestre recibió definitivamente, como juro de heredad, Bélmez, así como el resto de la villa y tierra de Fuenteovejuna, todo ello con sus términos y jurisdicción civil y criminal alta y baja, mero y mixto imperio, portazgos, escribanías, etc. ${ }^{157}$

La ocupación de Bélmez y su castillo resultó difícil de realizar por el maestre. Todavía el 3 de julio de 1450 no lo había conseguido. Ese día, cumpliéndose el plazo de 10 meses impuesto por el rey para el depósito de las cartas de donación en manos del prior de Guadalupe y deseando demostrar sus derechos al lugar, mandó sacar en Trujillo una copia de las mismas ${ }^{158}$. La solución vino dada en una hábil maniobra del rey, gestada, sin duda, por el condestable o el propio don Gu-

153 CARRILLO DE HUETE, p. 519.

154 Carta de 28 de agosto de 1449, en CABRERA MUÑOZ, pp. 405-406.

155 1449, septiembre, 1, en I. PASTOR BODMER, pp. 253-254.

156 Cit. en CABRERA MUÑOZ, op. cit., pp. 137-138, nota n.․․ 29.

157 Cit. en CABRERA MUÑOZ, p. 138, nota n. -30 , pp. 414-415, doc. 18.

158 Ibídem, p. 160, nota n. 102. 
tierre, que consistió en poner en secuestro, durante cuatro meses, tanto la villa como su castillo, alzando todo pleito homenaje a quienes lo tuvieran contraído tanto con Córdoba como con el maestre. De esta forma podía efectuarse el traspaso de poderes sin necesidad de asediar el castillo ${ }^{159}$.

La suerte de don Gutierre corrió pareja en los meses de 1449 y 1450 a la de don Álvaro. El disfrute de nuevas mercedes y donaciones se correspondió con la nueva situación que disfrutaba el valido. Hubo dos hechos que aprovechó don Álvaro en su beneficio en un intento por restablecer su liderazgo político. En primer lugar, se produjeron los primeros choques entre el príncipe y Pacheco. En 1450 se originó una importante ruptura de relaciones entre ambos, consecuencia, al parecer, de la enorme confianza que el heredero comenzaba a mostrar por Rodrigo Portocarrero, a quien otorgó el señorío de Medellín ${ }^{160}$. En un intento por asegurar su influencia en la corte, el marqués de Villena concertó el matrimonio de una hija bastarda suya, Beatriz, con el joven Portocarrero y, posteriormente, el 21 de octubre, él mismo se erigió en su protector al incluirlo en las confederaciones firmadas con el marqués de Santillana y el conde de Plasencia ${ }^{161}$. En segundo, estalló la guerra civil en Navarra entre Carlos de Viana y su padre, el rey don Juan. El condestable apoyó desde el primer momento la causa de Carlos para lo que buscó la alianza de Francia. De esta forma consiguió que Juan de Navarra firmase la paz con Castilla el 8 de diciembre de 1450, lo que equivalió, por parte aragonesa, a la disolución de la Liga.

Con la paz firmada consiguió el condestable alejar a los aragoneses de la política castellana. El debilitamiento del partido del príncipe fue su siguiente objetivo. En diciembre de 1450, don Gutierre de Sotomayor, a instancias del rey, tomó la villa de Medellín, emprendiendo el cerco de su castillo el 24 de ese mes. El hecho de que el ataque se hiciese sobre la villa del favorito de don Enrique, Pedro Portocarrero, en un momento de discordias entre rey y príncipe, nos da pie a conjeturar sobre las causas del mismo. Emilio Cabrera se preguntaba si la toma de Medellín demostraba la impotencia del maestre de Alcántara para llevar a la práctica la posesión de Bélmez y Fuenteovejuna, donadas el 8 de marzo. En mi opinión, no debe circunscribirse la toma de la villa al hecho de la resistencia opuesta por Bélmez y Fuenteovejuna a la ocupación de éstas por don Gutierre sino, más bien, al enfrentamiento en que se hallaban inmersos Juan II y el príncipe heredero. De hecho, una vez que ambos se reconciliaron en Tordesillas, el 21 de febrero de 1451, se ordenó al maestre, el 15 de marzo, el cese del cerco que tenía impuesto sobre el castillo, así como que dejase la villa libre para el príncipe.

159 Ibídem, p. 160, nota n.ำ 103, pp. 415-416.

160 El príncipe dio Medellín a Portocarrero el día 15 de noviembre, cit. en DEL PINO GARCÍA, p. 156, nota $\mathrm{n} . \stackrel{\circ}{3} 36$.

161 Cit. Ibídem, p. 191, nota n.ำ 133. La confederación respondió al intento de consolidar el partido enriqueño por parte de Juan Pacheco. 
A partir de aquí, parece que la actuación de don Gutierre no se relaciona tanto con los asuntos de la Corte como con los de su maestrazgo y patrimonio familiar. Puede incluso llegar a darnos la sensación de que, en previsión de lo que pudiera ocurrirle, el maestre se decidiese por arreglar la situación de su familia y bienes. Así, a lo largo de 1451 y 1452 lo vemos desarrollando una frenética labor diplomática, sobre todo con la Corte Pontificia, en aras a conseguir sus deseos. Muñoz de San Pedro apunta cómo, a través de la concesión de las distintas bulas papales que apoyaron sus peticiones, don Gutierre resolvió sus «...problemas de conciencia, el porvenir de los hijos y la fundación de vínculos» ${ }^{162}$.

Pero los acontecimientos seguían su curso y la serie de victorias conseguidas por el condestable, prácticamente en todos los frentes que tenía abiertos en su contra, provocaron nuevamente los recelos y deseos de destruirlo. No deja de resultarnos cuanto menos paradójico que en la confederación firmada el 21 de mayo de 1452 entre el conde de Benavente, Alfonso de Pimentel, y el conde de Santa Marta, en un momento en el que el conde de Benavente se hallaba fugitivo $^{163}$, se salvase y reservase al maestre de Alcántara junto a los principales miembros de la nobleza opositora a don Álvaro' ${ }^{164}$. Las noticias de que disponemos sobre la actuación de don Gutierre en estos meses de confederaciones, intrigas, e intentos de asesinato del condestable, que anteceden a su prisión y muerte, son más bien escasas ${ }^{165}$. ¿Puede ayudarnos a explicar esta ausencia de datos el que uno de los más firmes opositores del momento, el conde de Plasencia, fuese pariente de don Gutierre? ${ }^{166}$ ¿Apoyó el maestre de Alcántara, como tantas otras veces había ocurrido, a don Álvaro de Luna en el intento de conquistar Béjar? Todo parece indicar que el maestre se inclinó por conservar la alianza con los Stúñigas, consciente de los beneficios que le reportaría a su hijo Alfonso en una coyuntura, además, en que la oposición de Córdoba a que ocupase las villas donadas por el rey era manifiesta ${ }^{167}$. Quizás sea por ello por lo que encontramos a don Gutierre,

162 MUÑOZ DE SAN PEDRO, pp. 73-74.

163 SUÁREZ FERNÁNDEZ, Los Trastámaras en..., p. 208.

164 Cit. I. PASTOR BODMER, pp. 333-335.

165 Al parecer corrieron rumores de que don Álvaro, temeroso de su inminente caída, se había confederado con muchos Grandes y Señores del Reyno y fuera de él, y que entre otros era uno el Maestre D. Gutierre de Sotomayor (...) Era esta confederación contra sus enemigos y contra el Rey si le pretendiese quitar su Casa y Estado. TORRES Y TAPIA, p. 334. El propio Torres y Tapia no da pábulo en su crónica a estos rumores.

${ }^{166}$ El matrimonio concertado entre el hijo de Don Gutierre, don Alfonso, y la nieta de Pedro de Stúñiga, Elvira —-cuyas capitulaciones fueron firmadas en 1446-, se había celebrado hacia 1450. CABRERA MUÑOZ, p. 163.

${ }_{167}$ Las amenazas de Córdoba no eran infundadas. Aproximadamente un año después, en febrero de 1453, Córdoba emprendió una poderosa empresa de agresión con el fin de recuperar, por la fuerza, sus antiguas villas. Pedro de Aguilar, alcalde mayor de la ciudad, y el mariscal Diego Fernández, alguacil mayor de ella, fueron los designados para dirigirla. A ello contribuyó, sin lugar a dudas, el estado de relativa tranquilidad que se vivía en Córdoba, consecuencia de la concordia firmada el 14 de noviembre de 1452 en Castro del Río. Entre los firmantes se hallaban don Pedro Fernández de Córdoba, señor de Aguilar y don Diego Fernández de Córdoba, señor de Cabra, cabezas, respectivamente, del bando aguilarista y cabrista, principales protagonistas del enfrentamiento de bandos en que se hallaba sumida la ciudad, en I. PASTOR BODMER, pp. 340-342. 
en los primeros meses de 1453, fuera de todo contacto con la Corte y lo que en ella acontecía, apoyando en un ámbito bien distinto las reivindicaciones de su sobrino don Alonso de Monroy, clavero de la orden de Alcántara. Así, en febrero, en unión de su sobrino, estaba sitiando el castillo de Monroy, el cual se le rindió en el mes de septiembre ${ }^{168}$. Por lo tanto, cuando se produjo la prisión y muerte de aquél que había sido su valedor durante tanto tiempo, don Gutierre aún continuaba luchando ante los muros del castillo de Monroy, - ¿ajeno? - a los negros episodios vividos por don Álvaro de Luna.

¿Qué pensamientos corrieron por la cabeza de don Gutierre de Sotomayor al enterarse de la noticia? Muñoz de san Pedro, en ese tono romántico y laudatorio que caracteriza su estudio, nos muestra a un Sotomayor que, «...viendo hundirse su mundo, volvió, ya para siempre, a la vida de retraimiento». ${ }^{169}$

\section{CONSOLIDACIÓN DE SU STATUS PERSONAL Y PROYECCIÓN DEL LINAJE}

Una de las bases sobre las que se asentó la consolidación del poder noble en la Baja Edad Media fue la de las estructuras familiares. La sangre se afirmó como criterio determinante, y la importancia del principio hereditario invadió todo el orbe nobiliario. La organización en linajes -rígida estructura de organización familiar nobiliaria fundamentada en la sangre, así como su extensión natural hacia otros círculos de relaciones clánicas, vasalláticas y clientelares- hizo cristalizar esa estructura de poder, en la que sus integrantes se encontraban vertebrados genealógicamente, sobre bases y líneas de solidaridad cada vez más firmes ${ }^{170}$. El linaje dio fuerza y originalidad a la nobleza conteniendo, al mismo tiempo en sí mismo, algunas causas de debilidad. En el intento de solucionar las mismas vino a contribuir poderosamente el mayorazgo. El triunfo del mayorazgo, como práctica sucesoria que establecía un régimen de propiedad vinculada en beneficio del pariente mayor del linaje, acababa así con la amputación de los patrimonios, un hecho que fomentaba la constante renovación y la frágil cohesión de esta categoría social ${ }^{171}$. Por lo tanto, la aparición del mayorazgo, que alcanzó su consolidación de-

168 MUÑOZ DE SAN PEDRO, pp. 74-78. Fueron estas circunstancias, también, las que aprovecharon los cordobeses para iniciar su ofensiva contra las posesiones de don Gutierre.

169 Ibídem, p. 78. La desaparición de don Álvaro de escena no significó la pérdida del favor de don Gutierre respecto de Juan II, como lo demuestra el hecho de que, ocupadas por Córdoba algunas villas del señorío de don Gutierre, el rey ordenase a Córdoba su devolución. 1453, septiembre, 18. Valladolid, Colección, doc. 996.

170 M. ${ }^{a}$ CONCEPCIÓN QUINTANILLA RASO, Nobleza y caballería en la Edad Media, Madrid, 1996, p. 60.

171 M. a CLAUDE GERBET, Las noblezas españolas en la Edad Media. Siglos XI-XV, Madrid, 1997, p. 338.

172 En su instauración debemos ver, una vez más, su relación con la conciencia del linaje que de sí misma tiene la nobleza bajomedieval; en la representación mental de esta clase social, el prestigio y la influencia de la familia son contemplados como indisolublemente vinculados a la disponibilidad del mayor número de rentas y patrimonios. Su acumulación en una sola mano convierte, por tanto, al jefe del lina- 
finitiva bajo los Trastámara y, sobre todo, en el siglo XV, contribuyó considerablemente a estructurar al linaje noble 0 , más exactamente, a definir e individualizar en el interior del mismo una línea primogénita ${ }^{172}$. En otro sentido no menos importante, el mayorazgo, institución directamente relacionada con una acción programada de legitimación y propaganda del linaje y del individuo, a partir de la jefatura del linaje, convertida en la representación misma de dicha organización, asumió la función de engrandecimiento de la estructura familiar y de proyección de sus valores y poderes. Algo para lo que la nobleza contó con la monarquía como agente propagandístico que, en otros aspectos, como argumento justificativo de su decisión, incorporaba las referencias a los servicios realizados por el individuo y sus antecesores, dando proyección social a los mismos ${ }^{173}$.

A lo largo del presente trabajo hemos sido testigos, e intentado profundizar, en la carrera de don Gutierre de Sotomayor, fundador del linaje y principal artífice de la grandeza de la familia: primero, y al amparo de su tío don Juan de Sotomayor, maestre de Alcántara, escalando posiciones en la propia orden, llegando a ser Comendador Mayor de la misma y después maestre; después, y una vez controlados los resortes internos de la orden, lanzarse junto a don Álvaro de Luna al plano de la política interna del reino. Como el resto de hombres nuevos de la época, don Gutierre aspiró a fundar un mayorazgo ${ }^{174}$. La conciencia de linaje, muy fuerte en aquellos tiempos, y su especial vinculación a Juan II y a don Álvaro de Luna, en una época en que los servicios al rey solían premiarse con la concesión de señoríos, hicieron posible la consumación de este deseo ${ }^{175}$. Con ello, vio don Gutierre cumplidas con creces sus aspiraciones alcanzando, por una parte, una preeminencia social y económica envidiables y, por otra, siendo el ca-

je [dependiendo de la familia, ya que también existían mayorazgos de menor entidad en virtud del rango y nivel de riqueza de la misma], en uno de los hombres más poderosos del reino y, con él, a toda su familia; la división de esas posesiones comporta, por el contrario la pérdida del poder socioeconómico de las familias y la desaparición del linaje de entre los primeros puestos de la escala social. Los contemporáneos supieron entender perfectamente esta idea y así la expresaron habitualmente en las cláusulas de la fundación de los mayorazgos, como una especie de justificación del hecho mismo de vincular la mayor parte de los bienes al primogénito varón ante los ojos de los restantes hijos y parientes. I. BECEIRO PITA Y RICARDO CÓRDOBA DE LA LLAVE, Parentesco, poder y mentalidad. La nobleza castellana, siglos XII-XV, Madrid, 1990, p. 234.

173 M. ․ CONCEPCIÓN QUINTANILLA RASO, «La Nobleza», en Orígenes de la Monarquía Hispánica: propaganda y legitimación (ca. 1400-1520), p. 89-90.

${ }_{174}$ El mayorazgo medieval anterior a las Leyes de Toro (1505) tenía como particularidad el que no podía constituirse ni modificarse en nada sin la autorización del soberano. No rigiéndose por ninguna ley propia, sino por la «costumbre» o, más bien, por una especie de jurisprudencia, siguió dependiendo considerablemente del rey, que se encargaba entre otras cosas de «dictar las leyes» en los casos litigiosos. M. ${ }^{a}$ CLAUDE GERBET, «Majorat, stratégie familiale et povoir royal en Castille. D après quelques exemples pris en Estrémadure à la fin du Moyen Age", Les Espagnes médiévales, aspects économiques et sociaux. Mélanges offerts á Jean Gautier-Dalché, Annales de la faculté des lettres et sciences humaines de Nice, 1983, pp. 257-276.

${ }_{175}$ Lo corriente en la época era la concesión de un cargo o dignidad que llevasen anejos la percepción de unos ingresos más o menos cuantiosos; la asignación de una renta, inscrita en los libros del rey o la asignación de un determinado número de vasallos en una localidad; y, finalmente, la concesión de villas y tierras en señorío. CABRERA MUÑOZ, p. 93.

176 En CABRERA MUÑOZ, pp. 385-387, doc. 7. 
beza de un nuevo linaje que supo emparentar con alguna de las familias más importantes del reino.

Había, si embargo, escollos difíciles de resolver. En primer lugar, debido a su condición de caballero reglar profeso, no podía contraer matrimonio ${ }^{176}$. En una época en que la transmisión de la nobleza resultaba imposible fuera del matrimonio legítimo, la consecuencia inmediata era que los hijos habidos por el maestre eran ilegítimos ${ }^{177}$. Junto a este primer problema que se le presentaba a don Gutierre, e íntimamente relacionado con el mismo, se hallaba la imposibilidad de transmitir la dignidad de Maestre de la Orden de Alcántara, ya que tal dignidad no era hereditaria. Por último, la fundación de un mayorazgo implicaba la posesión de unos determinados bienes con que poder dotar a los sucesores, generalmente en forma de señoríos, algo que la condición de maestre tampoco llevaba aparejado. Problemas a los que don Gutierre supo dar respuesta, sabedor de que tanto las personas como los hilos que había que mover estaban de su parte.

\subsection{Concesión de mercedes}

Como no podía ser de otra forma, la adscripción —desde los primeros momentos- de don Gutierre de Sotomayor al partido encabezado por don Álvaro de Luna le reportó considerables beneficios, en su mayoría traducidos en la concesión de una serie de villas y territorios en condición de señoríos.

El primero de estos hitos se produjo tras la destacada intervención de don Gutierre en la defensa de Sevilla y posterior expulsión del infante don Enrique de Córdoba, Carmona y Alcalá de Guadaira. Juan II, en recompensa a tales servicios, expidió, el 6 de noviembre de 1444, dos albaláes a favor de Don Gutierre, notificándole la concesión de Gahete e Hinojosa por juro de heredad, con sus vecinos y moradores, distritos y términos, rentas, pechos y derechos, jurisdicción civil y criminal alta y baja, mero y mixto imperio etc.; facultándole, de igual modo, para que pudiera traspasarla a sus herederos y sucesores ${ }^{178}$.

La segunda de las mercedes concedidas, La Puebla de Alcocer con su vizcondado, se produjo al parecer, debido a la presión ejercida por el propio Gutierre de Sotomayor sobre el monarca. La villa, situada en las cercanías de la encomienda de Lares, era comarcana de los territorios de la orden de Alcántara desde el siglo XIII. Constituía una pieza muy apetecible para don Gutierre, puesto que lindaba, a un tiempo, con las tierras de la orden y con el extremo septentrional del término de Gahete, del cual estaba separada por una jornada de camino a través de

177 JAVIER ORTEGA ÁLVAREZ, pp. 274-275.

178 1444, noviembre, 6, (incluido en privilegio rodado de Fuentes de Sauco, 1445, agosto, 30), en CABRERA MUÑOZ, p. 121.

179 Ibídem, pp. 121-122.

180 Colección, doc. 929. 
las encomiendas de Cabeza del Buey y Lares. Debido a esas circunstancias fue seguramente La Puebla, de todas las villas del señorío de los Sotomayor, la que, desde el primer momento, despertó el mayor interés en el maestre de Alcántara ${ }^{179}$. Por otra parte, ya el 10 de enero de 1441, el rey se la había concedido en tenencia como respuesta a las afrentas sufridas por parte de la ciudad de Toledo ${ }^{180}$. El 7 de abril de 1445 Juan II concedió La Puebla de Alcocer con los mismos derechos, rentas y atribuciones con que le habían sido otorgadas, medio año antes, las villas de Gahete e Hinojosa. Asimismo, Juan II facultaba expresamente al maestre de Alcántara para que pudiera formar con todas las villas citadas un mayorazgo a favor de su hijo Alfonso de Sotomayor ${ }^{181}$.

La afortunada participación de don Gutierre en la batalla de Olmedo supuso otro hito importante para su engrandecimiento personal. A la derrota de los infantes de Aragón siguió, como en otras ocasiones, la confiscación y distribución de sus bienes. Don Gutierre de Sotomayor obtuvo una doble prebenda: por una parte, la confirmación, en sendos privilegios rodados expedidos en Fuente Sauco, el 30 de agosto de 1445 , de la merced de Gahete e Hinojosa ${ }^{182}$. Por otra, recibió la villa de Alconchel, próxima a la frontera de Portugal ${ }^{183}$.

Si bien el núcleo de sus posesiones quedaba prácticamente constituido, aún recibiría don Gutierre otra serie de donaciones y mercedes ${ }^{184}$, como la que recibió con motivo de su participación junto al condestable en el intento de atajar la rebelión de Toledo, sublevada como consecuencia del pretendido cobro de un empréstito por parte de don Álvaro. El 28 de agosto de 1449, Juan II le hizo merced de 400 vasallos situados en los lugares de Bélmez (Córdoba) y Milagro (Toledo) ${ }^{185}$. Días después, sin embargo, el monarca dejó en suspense el disfrute de la merced, estableciendo un plazo de diez meses durante el cual el título de la misma quedaría en depósito del prior del monasterio de Guadalupe. Si, pasado el plazo, no había otorgado el rey al maestre los 400 vasallos en lugar distinto, Bélmez y Milagro pasarían a formar parte de los señoríos del maestre. Juan II se comprometía a donar igualmente los términos de Espiel, que le habían sido pedidos por el maestre ${ }^{186}$.

Antes de cumplirse el plazo, el 20 de octubre, Juan II le dio la villa de Medellín, con su castillo, términos, jurisdicción..., en compensación de los 400 vasallos de Bélmez y Milagro. La merced era transitoria, hasta que el rey no obtuviera la villa

181 1445, abril, 7. Arévalo, en CABRERA MUÑOZ, p. 122 (EI 20 de mayo de 1447 le fue confirmada La Puebla mediante privilegio rodado, cit. en MUÑOZ DE SAN PEDRO, p. 67).

182 1445, agosto, 30. Ibídem, p. 124.

183 CARRILLO DE HUETE, p. 468. Con Alconchel formaría un mayorazgo para su hijo Juan.

184 En este sentido, casi podríamos considerar de merced, aunque lógicamente no se trate ni mucho menos de ello, el deslinde de términos efectuado por el bachiller Piedrafita para las villas de Gahete e Hinojosa, cuya sentencia fue promulgada el 27 de mayo de 1447, ya que las villas recibieron términos amplísimos, comprendiendo incluso dentro de ella una parte considerable de la villa de Fuenteovejuna y de su tierra, que pasó así a formar parte del señorío de don Gutierre. CABRERA MUÑOZ, p. 134.

185 1449, agosto, 29. Ibídem, pp. 405-406.

186 1449, septiembre, 1. PASTOR BODMER, pp. 253-254.

187 Cit. CABRERA MUÑOZ, p. 138. 
de su hijo, a quien pertenecía en ese momento. Caso de que no ocurriese así, Juan II cumplimentaría la merced de los 400 vasallos localizándolos en Fuenteovejuna, al tiempo que prometía concederle el lugar de Bélmez ${ }^{187}$. El 8 de marzo de 1450, don Gutierre de Sotomayor recibía definitivamente como juro de heredad, Bélmez, así como el resto de la villa y tierra de Fuenteovejuna, todo ello con sus términos y jurisdicción civil y criminal alta y baja, mero y mixto imperio, portazgos, escribanías, etc. ${ }^{188}$

Con la adquisición de estos señoríos don Gutierre salvó con creces el primer escollo hacia la fundación de mayorazgos. Aún quedaban otros por sortear.

\subsection{Legitimaciones}

Como hemos apuntado, para llevar a cabo el traspaso de bienes y la fundación de un mayorazgo era indispensable la legitimidad de los hijos sobre los que iba a recaer tal concesión. Habida cuenta de la dignidad que encarnaba don Gutierre, no cabía la menor duda de la ilegitimidad de sus posibles y futuros herederos; una situación que don Gutierre, consciente de ella, intentó reconducir desde los primeros momentos.

Ya en 1437 obtuvo del monarca la legitimación de su hijo Alfonso; una legitimación que así como el papa ha poder de legitimar en lo espiritual, así los reys avemos poder de legitimar en lo temporal a los que no son nasçidos de legítimo matrimonio ${ }^{189}$. El monarca legitimaba a Alfonso, a petición de Gutierre de Sotomayor, para poder tener bienes y heredarlos, así como para tener todas las onrras e franquizias e oficios e merçedes e libertades que han e deven aquel o aquellos que son legítimos e de legítimo matrimonio nacidos ${ }^{190}$. De esta forma fue introducido en el mundo de la corte, siendo doncel del rey, del cual obtuvo un juro de heredad por una cuantía de 98.000 maravedíes anuales ${ }^{191}$.

El 7 de abril de 1445, junto a la merced de La Puebla de Alcocer, facultó el rey a don Gutierre para poder fundar un mayorazgo con las villas de Gahete, Hinojosa y La Puebla de Alcocer con su vizcondado en favor de su hijo Alfonso ${ }^{192}$. Dos años después, siempre al hilo de la incontestable fidelidad de don Gutierre para con el monarca, el 31 de agosto de 1447, éste, en premio a toda su carrera y en atención a los señalados servicios prestados contra los infantes de Aragón en Andalucía y Olmedo, le facultaba para crear mayorazgos en sus villas de Puebla de Alcocer,

188 1450, marzo, 8, CABRERA MUÑOZ, pp. 414-415.

189 1437, septiembre, 4. Medina del Campo, CABRERA MUÑOZ, pp. 385-387, doc. 7.

190 Ibídem.

191 AGS. Mercedes y Privilegios, leg. 36, fol. 73.

192 1447, abril, 7. Arévalo, Colección, doc. 947.

193 1447, agosto, 31. Madrigal, Colección, doc. 959. 
Gahete e Hinojosa, para don Alfonso o cualquiera de los otros hijos habidos, a los que legitimaba y capacitaba para recibirlos ${ }^{193}$.

Con estas mercedes, don Gutierre de Sotomayor consiguió de Juan II la legitimidad de sus hijos y la posibilidad de que éstos pudieran heredar y ser titulares de un mayorazgo.

\subsection{Dispensas y autorizaciones}

Quedaba por franquear un último obstáculo. Poseedor de bienes patrimoniales propios al margen de la orden, legitimados sus hijos para recibirlos, aún debía solventar el siempre espinoso asunto de las dispensas y autorizaciones papales. Para conseguirlo emprendió don Gutierre una frenética labor diplomática con la Corte Pontificia, ya que no le bastaba sólo con la facultad del rey para disponer de su riqueza y fundar mayorazgos a favor de sus hijos, por cuanto quedaba obligado por los votos de castidad y pobreza que implicaba pertenecer a la orden y por la obediencia debida al Pontífice. Recurriendo a Nicolás V, obtuvo de éste aquello que demandaba, sucediéndose una serie de bulas a su favor.

Nicolás $\mathrm{V}$, atendiendo a las muchas adquisiciones, mejoras y reparaciones que el maestre Gutierre de Sotomayor había hecho a la mesa maestral y a la orden de Alcántara, le autorizó a testar hasta 20.000 florines de oro a favor de sus hijos, familiares, allegados y servidores de aquellos bienes por él adquiridos que no se hubieran incorporado a la orden, o sobre los que ésta mantuviera expectativas ${ }^{194}$. Pero aún consiguió más, ya que el 1 de octubre de 1451 obtuvo del papa la confirmación de las donaciones realizadas anteriormente de sus propias ganancias a sus hijos, familiares, amigos y servidores, cualquiera que hubiese sido su valor, salvo aquellas que hubieran sido consignadas a la orden o a alguna iglesia o altar. Además le facultó - he aquí la importancia de la bula-, para poder disponer en el futuro de cualesquiera otras ganancias con la misma libertad o capacidad que si fuera un caballero secular no profeso ${ }^{195}$. De esta forma, desligaba toda su fortuna de la obligada dependencia a la orden, imponiendo pena de excomunión a quien lo contradijese.

Pero si bien sus peticiones fueron atendidas positivamente, aún quedaban algunos flecos por resolver. Entre otros los asuntos relativos a algunos de sus hijos. Como los de Alfonso que, en posesión ya de la fortaleza de La Puebla de Alcocer, mantenía un conflicto abierto con la orden de Alcántara por haberse edifi-

\footnotetext{
194 [1451], Roma, Colección, doc. 984.

195 1451, octubre, 1. Roma, Colección, doc. 987.

196 Recordemos que la fortaleza de La Puebla fue reparada y edificada por Gutierre de Sotomayor merced a la licencia y facultad otorgada por Juan II. 1446, febrero, 20, Colección, doc. 953.

197 1451, octubre, 1. Roma, Ibídem, doc. 986.

198 [1451], Roma, Ibídem, doc. 983.
} 
cado la fortaleza sobre tierras en parte pertenecientes a la encomienda de Lares ${ }^{196}$. Nicolás V dio poderes al prior de Guadalupe, a instancias de don Gutierre de Sotomayor, para que, en su caso, autorizase la permuta de algunas tierras u otros bienes entre la orden y Alfonso de Sotomayor para solucionar de esta forma el conflicto $^{197}$. O el caso de Fernando de Sotomayor, clérigo de la diócesis de Coria, al cual Nicolás V, por intercesión de su padre, dispensó de mencionar en lo sucesivo su defecto de natalidad en cualquier promoción a hábitos o beneficios eclesiásticos de cualquier catedral, colegiata, etc., a los que pudiera ser promovido ${ }^{198}$; así como de la ley eclesiástica que prohibía acumular dos beneficios o dignidades en una persona, salvo si se trataba de iglesias parroquiales o vicarías perpetuas ${ }^{199}$.

Con todo ello don Gutierre tuvo, por fin, el camino expedito para la fundación de los mayorazgos.

\subsection{Mayorazgos}

La institución de los mayorazgos efectuada por don Gutierre de Sotomayor tuvo lugar el mismo día que otorgó su testamento. Uno y otro documento llevan la misma fecha, Zalamea, 12 de octubre de $1453^{200}$. Una larga serie de disposiciones articulan el funcionamiento de ambos mayorazgos con una casuística muy típica de la época, resumida de la siguiente forma ${ }^{201}$ :

1. Don Alfonso de Sotomayor recibiría las villas de Puebla de Alcocer, Herrera, Fuenlabrada, Helechosa, Villarta, Alía, Valdecaballeros, Castilblanco y Sevilleja, así como el lugar de Milagro, todas ellas en el reino de Toledo. Pasaban igualmente a don Alfonso, Gahete, Hinojosa, Bélmez, Fuenteovejuna y el condado de Espiel, en Córdoba.

2. Don Juan de Sotomayor recibía la villa de Alconchel, con su castillo, términos, jurisdicción y vecinos, en idénticas circunstancias que su hermano Alfonso.

3. Ambos mayorazgos se transmitirían de padres a hijos a través del hijo mayor legítimo de su descendencia, agotada la cual se llamaba a la sucesión a las hembras ${ }^{202}$.

199 1451, octubre, 6. Roma, Colección, doc. 989.

200 Emilio Cabrera tiene la certeza de que, aunque ambos documentos estén fechados el mismo día, se estructuraron en época distinta: seguramente el de la institución del mayorazgo con antelación al del testamento. 1453, octubre, 12, CABRERA MUÑOZ, pp. 416-422, doc. 20.

201 Sigo el resumen expuesto por CABRERA MUÑOZ, pp. 165-167.

202 En los mayorazgos se encuentra la mayor insistencia en la masculinidad y en la primogenitura y, en definitiva, en el mismo linaje. El orden de sucesión habitual es el de agnación masculina, recayendo la sucesión en mujeres en el caso de la ausencia de varón. I. BECEIRO PITA y RICARDO CÓRDOBA DE LA LLAVE, p. 90. 
4. Si sobrevenía la muerte de don Alfonso sin dejar hijo ni heredero legítimo, sus estados debían pasar a don Juan, y viceversa. En el caso de que ambos hermanos murieran sin descendencia legítima, el mayorazgo debía pasar a ciertos hijos del maestre o a los descendientes de éstos, por este orden: en primer lugar don Fernando de Sotomayor, seguido luego por sus hermanas doña María, doña Teresa y doña Catalina. Los restantes hijos del maestre no eran llamados a la sucesión.

5. Si don Alfonso, don Juan o alguno de sus descendientes muriera con posterioridad a su hijo mayor heredero, habiendo dejado éste, a su vez, un hijo varón, éste sólo sería llamado a la sucesión en el caso de que el último titular efectivo del señorío no dejara otros hijos varones, puesto que, en esa circunstancia, el segundogénito (o, en su defecto, sus restantes hermanos varones) debía ser siempre preferido al nieto incluso en el caso de que tal nieto fuera de mayor edad que el hijo en cuestión.

6. Don Alfonso, don Juan o sus sucesores no podrían enajenar, en todo o en parte, los bienes de su mayorazgo por ningún concepto; la enajenación, si la hicieren, quedaría sin valor y el culpable perdería sus derechos al mayorazgo.

7. Debían conservar igualmente el apellido Sotomayor y usar las mismas armas y divisas de don Gutierre, sin mezclarlas con otras ${ }^{203}$.

8. Les instaba asimismo a que pertenecieran siempre en la obediencia de Juan II, del príncipe Enrique y de sus sucesores, pero estipulaba que, aún en el caso de que alguno de ellos cometiera contra los reyes delito de alta traición y se hicieran por ello acreedores a la confiscación de sus bienes, el culpable debía ser tenido por muerto y heredaría sus estados la persona que más derecho tuviera a hacerlo ${ }^{204}$.

203 La obligación omnipresente en el establecimiento de todo mayorazgo era que el nuevo titular tomase las armas, voz y apellido del linaje posesor, lo que resultaba un paso obligado para marcar la continuidad dentro de una misma familia a los ojos de otros nobles, vasallos y habitantes del dominio, de la misma manera que en algunas tomas de posesión uno de los elementos simbólicos del cambio de señor era borrar las armas del antiguo para poner las del nuevo. Ibídem, p. 94.

204 Expresión de hasta qué punto el carácter de los bienes amayorazgados eran propios del linaje y no del individuo, lo constituían este tipo de cláusulas contenidas en los mayorazgos. Existía un consenso en todos ellos: este acto reprobable, que iba contra las recomendaciones de alguno de los fundadores de continuar en el servicio del monarca actual y sus descendientes no suponía el paso del señorío vinculado, a la Corona, sino que el titular era considerado reo de delitos o crímenes graves que tenían como pena la confiscación, siendo desposeído del dominio, pasando éste al siguiente en orden de sucesión. Ibídem, p. 93.

205 El cuidado puesto en la conservación del patrimonio se plasmaba igualmente en las cláusulas restrictivas. En este sentido suponía una constante la pérdida de derechos del descendiente que pertenecía al clero regular y secular, y que no podía dejar su estado. Era evidente que su objetivo consistía en impedir la anexión del dominio por los eclesiásticos. Ibídem, p. 91. El que don Gutierre exceptuase a su hijo Fernando de tal cláusula pensamos responde a las dispensas que éste obtuvo del papa Nicolás V. 
9. Ninguno de sus herederos podría ganar licencia del Papa o del rey para enajenar todos o parte de los bienes sujetos a mayorazgo, el cual, por otra parte, no podía pasar a religioso profeso ni clérigo de orden sagrada, con la excepción de su hijo Fernando, si tal caso llegara a ocurrir ${ }^{205}$.

10. Don Alfonso y don Juan quedaban autorizados a partir de entonces para posesionarse de sus respectivos señoríos, cuyo traspaso les hacía su padre en ese momento.

Lo primero que nos llama la atención es la fundación de más de un mayorazgo. Usualmente, entre las familias de la media y media-alta nobleza, sólo existió un mayorazgo, integrado por los bienes patrimoniales y, si acaso, por una pequeña aportación de la madre. Entre las familias de la más alta aristocracia, la tendencia fue más bien la de fundar más de un mayorazgo, al menos dos o tres, para los hijos varones y, aunque ello no fue posible en todos los casos, se llevó a cabo en repetidas ocasiones. El caso de don Gutierre de Sotomayor vemos que armoniza perfectamente con esta segunda opción, lo que nos indica la elevada posición social alcanzada. De igual modo se puede apreciar que el mayorazgo instituido en favor de don Alfonso fue el de más categoría, tanto por el número como por la importancia de las villas concedidas. Esto era lo que solía ocurrir en los supuestos en que se configuraban dos mayorazgos: el fundado para el primogénito tendía a reunir las características comunes a los mayorazgos únicos, es decir, en él quedaban vinculadas las posesiones más cuantiosas, las villas y fortalezas principales, y con frecuencia también el solar originario de la familia ${ }^{206}$. Pero no solamente era beneficiario este primogénito del mayorazgo familiar único o principal. Como tales hijos mayores, recibían una educación más especial, un mayor grado de responsabilidad en la gestión señorial desde su juventud y más ricas mujeres en matrimonio. Esto es algo perfectamente constatable en la persona de don Alfonso de Sotomayor: introducido en el mundo de la corte, fue doncel del rey, del cual obtuvo un juro de heredad por una cuantía de 98.000 maravedíes anuales; desde 1450 era ya señor de La Puebla de Alcocer, donde don Gutierre adquirió para él una serie de bienes inmuebles; fue por entonces cuando contrajo matrimonio con Elvira de Stúñiga, la menor de las hijas de Álvaro de Stúñiga y de Leonor de Manrique, en una primera aproximación de los linajes de Stúñiga y Sotomayor, que se fundirán definitivamente a comienzos del siglo XVI.

\section{CONCLUSIÓN GENERAL}

En la trayectoria personal y política de Don Gutierre de Sotomayor, personaje típico del siglo $\mathrm{XV}$, se resumen todos aquellos factores que hemos ido desgra-

206 Ya dijimos cómo Alconchel, en la frontera con Portugal, quedaba separado del resto de los dominios de don Gutierre de Sotomayor, un grupo mucho más compacto y homogéneo formado por Gahete, Hinojosa y La Puebla de Alcocer. 
nando y estudiando a lo largo de este trabajo. Dicha trayectoria vital constituye un fresco en el que se refleja y es posible observar las señas de identidad que caracterizaron a toda una época: aspectos económicos y sociales, políticos e institucionales, militares, etc.

Trasladado junto con su familia a las tierras del maestrazgo de Alcántara, pasó su niñez en Valencia, donde su tío, Juan de Sotomayor, era comendador de dicha encomienda. Criado, por lo tanto, en la Casa de su tío, entró a formar parte, desde muy temprano, de ese grupo de allegados, consanguíneos, oficiales y servidores, los clientes, instrumento indispensable en la vida cotidiana de cualquier noble de la época que se preciase de serlo.

La predilección mostrada por Juan de Sotomayor hacia su sobrino Gutierre como si de su primogénito se tratase- quedó reflejada en la fulgurante carrera recorrida por éste. Este hecho explica el grado de responsabilidad que desde muy joven alcanzó en la orden -Clavero antes de 1426, Comendador Mayor y del Portezuelo antes de 1431-, así como su inclusión en el mundo de la Corte ya hacia 1425, con el cargo de Guarda Mayor del Príncipe de Asturias. No cabe duda que en la cabeza de su tío, la sucesión del maestrazgo - tal que si fuese un mayorazgo- debía recaer en Gutierre.

La sucesión recayó efectivamente en él, pero no a través de los cauces diseñados por su tío. Inmerso en la dinámica de una época violenta y convulsa —caracterizada por una monarquía con altas pretensiones de centralización del poder y una nobleza anhelante de controlar al rey, fuente de ingresos y mercedes, y por el enfrentamiento de ambas opciones a través de bandos y ligas nobiliarias-, y exponente, como tantos otros, de una nobleza ávida de títulos y beneficios, adoptó la opción política que más beneficiaba a sus intereses en menoscabo incluso de su máximo valedor. Una dinámica de la que no pudo sustraerse la orden como institución, máxime desde que éstas se habían convertido en instrumentos de la política real en detrimento de aquellas primitivas señas de identidad que motivaron su aparición. De esta forma las rivalidades existentes en el reino se trasladaron a las órdenes en virtud del partido o bando elegido por sus dirigentes, provocando división de opiniones y posturas opuestas en su seno difícilmente conciliables. La acción que, como sabemos, llevó a don Gutierre de Sotomayor a lo más alto de la orden de Alcántara - recordemos, la prisión del infante don Pedro en 1432, en un momento en que se estaban dirimiendo en tierras extremeñas las diferencias entre los infantes de Aragón, que contaban con el inestimable apoyo del maestre de Alcántara, Juan de Sotomayor, y la monarquía de Juan II y don Álvaro de Lunarespondió no tanto a las circunstancias casuales de las que habló Quintana o al oportunismo defendido por Cabrera, que también, sino, más bien, al intento de cambiar la orientación política de la orden —ya apuntado por del Pino-, en virtud, sobre todo, de la opción política defendida por el comendador mayor y el grupo de opinión que se configuró en torno a su persona. 
Su adscripción al bando monárquico, encarnado en la figura de don Álvaro de Luna, personaje del que ya nunca se separaría, supuso la participación de don Gutierre en los principales acontecimientos que tuvieron lugar en su tiempo y un nuevo impulso a su trayectoria personal. Como no podía ser de otra forma, la orden de Alcántara, por extensión, se halló inmersa en dichos conflictos, aportando los ingentes recursos económicos y militares con los que contaba. Ahora bien, debemos tener siempre presente que es imposible desligar las dos facetas que se observan en don Gutierre a la hora de valorar su participación en dichos acontecimientos. Don Gutierre siempre va a ser el maestre de Alcántara, y dentro de lo que supone esta «imagen pública» estaba, entre otras cosas, la posibilidad de poder tejer, merced a la privilegiada posición que le proporcionaba tal dignidad, una amplia red de vínculos clientelares, imposible de no haberse dado tal circunstancia. Es con este importante aval, que obliga a amigos y adversarios a tenerlo siempre en cuenta, con el que se presenta en la escena política de su tiempo. Por otra parte, en íntima relación con lo anterior y derivado de ello, don Gutierre de Sotomayor es un elemento importante de uno de los bandos o ligas en que se halla dividido el reino; es entonces cuando se observa claramente su «imagen privada». Aquí se nos revela en toda su extensión la formidable clientela — familiares, amigos, criados, vasallos- manejada por don Gutierre a la hora de participar en tales eventos. ${ }^{207}$

Paradigma, como hemos apuntado, de ese sector que se alzó con la hegemonía social, económica, política y cultural de la sociedad bajomedieval, don Gutierre procuró perpetuar su memoria y la de su linaje — creado por él, no lo olvidemos- a través de la institución y fundación de mayorazgos en favor de sus hijos. Pretensión prácticamente inviable si nos atenemos a su particular situación, ello fue posible gracias a su enorme influencia tanto en las Cortes de Castilla como de Roma. La documentación nos indica el proceso seguido por don Gutierre. En primer lugar, legitimando a su numerosa prole y consiguiendo bienes con qué dotarlos por parte del monarca. En segundo, consiguiendo del pontífice las bulas necesarias para dejar de ser considerado caballero reglar profeso, y separar su fortuna personal de los bienes inherentes a la orden.

207 Vid. JAVIER ORTEGA ÁLVAREZ, op. cit., 3. Vínculos-Clientelas, pp. 270-286. 
